Review

\title{
Out-of-plane behavior of masonry infilled RC frames based on the experimental tests available: A systematic review
}

\author{
André Furtado ${ }^{a}$, Hugo Rodrigues ${ }^{\mathrm{b}, *}$, António Arêde ${ }^{\mathrm{a}}$, Humberto Varum ${ }^{\mathrm{a}}$ \\ a CONSTRUCT-LESE, Department of Civil Engineering, Faculdade de Engenharia da Universidade do Porto, Portugal \\ ${ }^{\mathrm{b}}$ RISCO, School of Technology and Management, Polytechnic Institute of Leiria, Portugal
}

\section{H I G H L I G H T S}

- A systematic review of out-of-plane behavior of infill walls out-of-plane is presented.

- Comparisons were drawn between the specimens to assess the impact on the panel response.

- Empirical relationships were proposed to predict the infill panels OOP capacity.

\section{A R T I C L E I N F O}

\section{Article history:}

Received 9 November 2017

Received in revised form 19 January 2018

Accepted 20 February 2018

\section{Keywords:}

Masonry infill walls

Seismic behaviour

Experimental studies

Out-of-plane behaviour

Masonry units

Mechanical properties

Previous damage

\begin{abstract}
A B S T R A C T
The primary objective of this manuscript is to present a systematic review of experimental studies regarding infill masonry walls out-of-plane (OOP) behaviour. An extended database was built containing information from each experimental campaign and specimen tested. Parameters such as geometric dimensions, material and mechanical properties, test setups and loading protocols and test results were collected. A systematic review methodology s conducted with the aim of filter the more relevant work in this field. For the analysis of each parameter in the infill wall OOP performance, three different groups were defined: as built specimens, specimens with previous in-plane damage and retrofitted specimens. Comparisons were drawn between the specimens of each group to assess the impact of those parameters on the panel response. Empirical relationships were proposed to predict the infill panels OOP capacity according to the aspect ratio, panel slenderness, percentage of masonry units' voids, masonry properties and previous in-plane drift. The results demonstrated that previous damage caused by in-plane tests that reached a maximum drift until $1.25 \%$ can reduce about $70 \%$ the OOP capacity of the panel, changing the failure mode of the panel that can result in fragile collapses. It was also observed that the parallel flexural strength parallel to the horizontal bed joints can increase the panel OOP maximum strength until 5 times.
\end{abstract}

(c) 2018 Elsevier Ltd. All rights reserved.

\section{Contents}

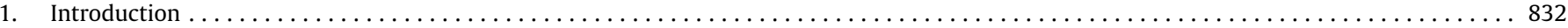

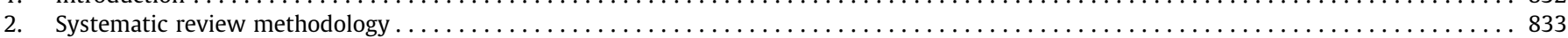

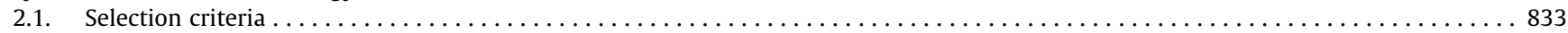

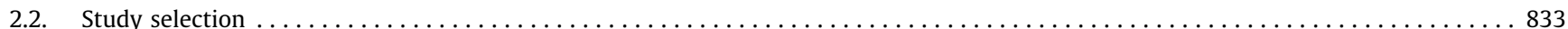

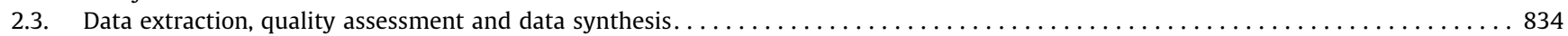

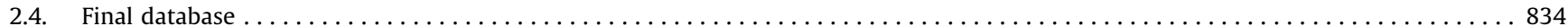

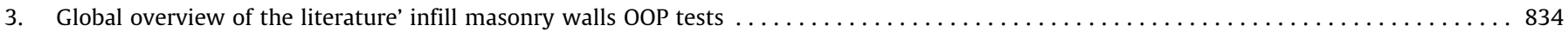

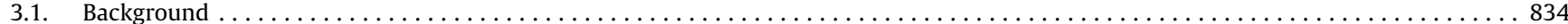

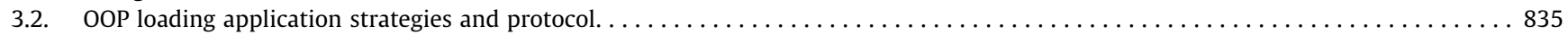

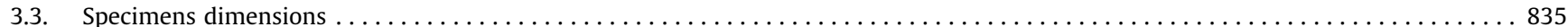

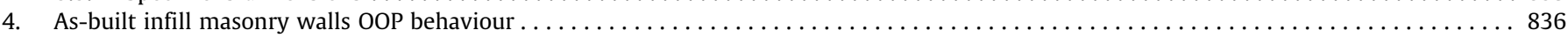

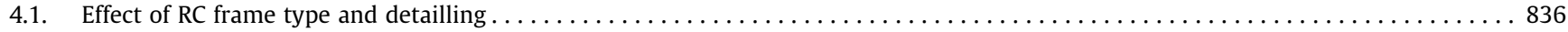

\footnotetext{
* Corresponding author.

E-mail address: hugo.f.rodrigues@ipleiria.pt (H. Rodrigues).
} 


\begin{tabular}{|c|c|c|c|}
\hline \multicolumn{4}{|c|}{ Nomenclature } \\
\hline \multirow[t]{2}{*}{$\mathrm{F}_{0.15 \mathrm{Fmax}}$} & Strength during the increasing phase corresponding to & $t$ & Panel thickness \\
\hline & $15 \%$ of the maximum strength & $\mathrm{f}_{\mathrm{mo}}$ & Mortar compressive strength \\
\hline \multirow[t]{2}{*}{$\mathrm{F}_{0.30 \mathrm{Fmax}}$} & Strength during the increasing phase corresponding to & $\mathrm{f}_{\mathrm{t}, \mathrm{mo}}$ & Mortar flexural strength \\
\hline & $15 \%$ of the maximum strength & $\mathrm{f}_{\mathrm{b}, \text { parallel }}$ & Masonry unit compressive strength parallel to the holes \\
\hline $\mathrm{F}_{\max }$ & Maximum strength & & direction \\
\hline $\mathrm{F}_{0.80 \mathrm{Fmax}}$ & $\begin{array}{l}\text { Strength during the decreasing phase corresponding to } \\
80 \% \text { of the maximum strength }\end{array}$ & $\mathrm{f}_{\mathrm{b}, \text { perpendi }}$ & $\begin{array}{l}\text { icular Masonry unit compressive strength perpendicular } \\
\text { to the holes direction }\end{array}$ \\
\hline & Ultimate strength reached by the panel & $\mathrm{f}_{\mathrm{m}}$ & Masonry compressive strength \\
\hline \multirow{2}{*}{$\mathrm{F}_{\text {crack }}$} & Strength reached by the panel at the formation of the & $\mathrm{E}_{\mathrm{m}}$ & Masonry elasticity modulus \\
\hline & first visible crack & $\mathrm{f}_{\mathrm{b}, \text { para }}$ & Masonry flexural strength parallel to the horizontal bed \\
\hline $\mathrm{K}_{\text {crack,sec }}$ & Secant cracking stiffness & & joints \\
\hline $\mathrm{K}_{\mathrm{sec}}$ & Secant stiffness & $f_{b, p e r p}$ & Masonry flexural strength perpendicular to the \\
\hline$K_{\text {ult,sec }}$ & Secant ultimate stiffness & & horizontal bed joints \\
\hline & Panel Height & $\mathrm{f}_{\mathrm{t}}$ & Masonry diagonal tensile strength \\
\hline $\mathrm{W}_{\mathrm{p}}$ & Panel Width & & \\
\hline
\end{tabular}

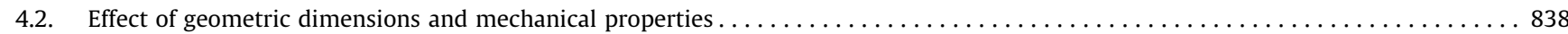

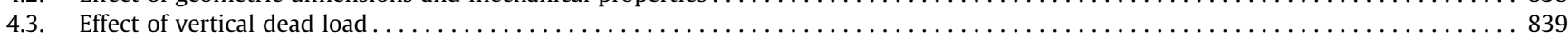

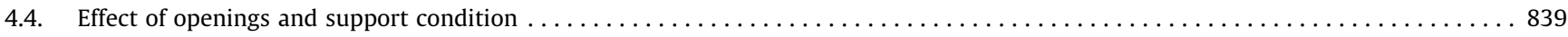

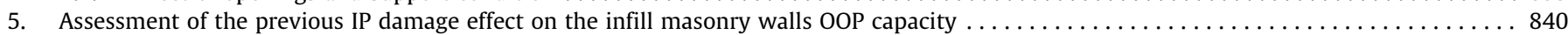

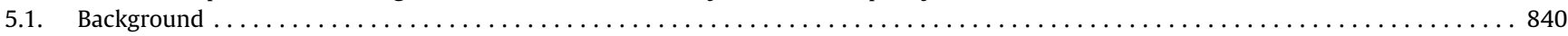

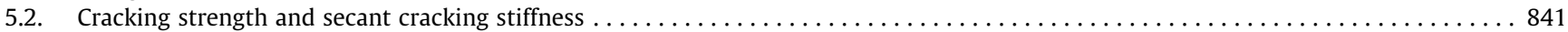

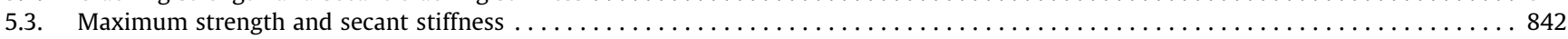

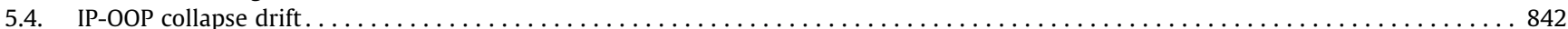

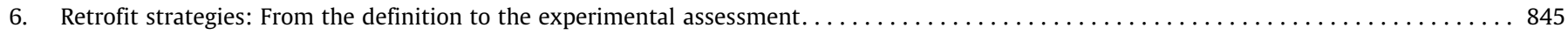

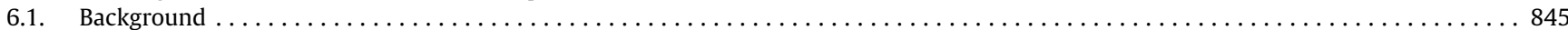

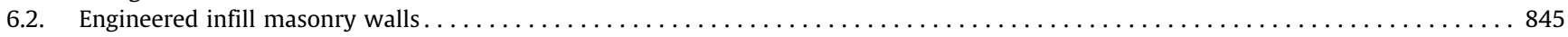

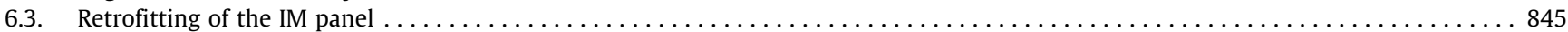

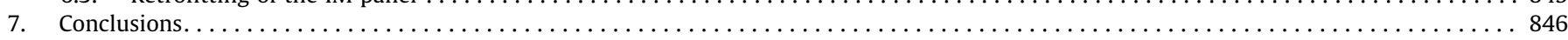

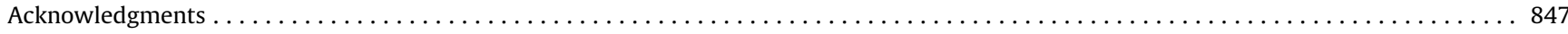

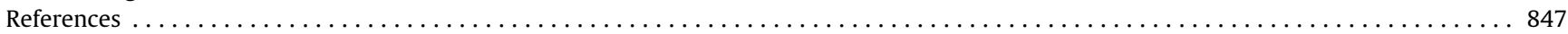

\section{Introduction}

The infill masonry walls are widely used for partition purposes and to provide also thermic and acoustic insulation to the reinforced concrete (RC) structures. Usually, the infill walls are considered non-structural elements and no special attention is given to them during the design process of new buildings and safety assessment of existing ones [34]. However, its poor performance was observed in recent earthquakes $[18,19,35,41,77]$ and in particular their out-of-plane (OOP) vulnerability when subjected to transversal loadings resulted in innumerous of collapses/extensive damages that in general increased significantly the risk to the population and the rehabilitation' costs of the buildings. The risk associated to this type of failure can be greatly increased due to constructive details aspects commonly adopted in the Southern countries of the Europe, such for example no connection between the panel and the surrounding RC elements, no connection between the leafs (in the case of double-leaf infill masonry walls) and insufficient width support condition of the panel.

Some in-situ survey reports after the Lorca (Spain) earthquake in 2011 emphasyzed the deficient infill masonry seismic performance [64]. Some OOP collapses were reported, associated to insufficient support of the panels (Fig. 1). Many authors pointed that the abcense of proper connection between the frame structure and the infill masonry wall increase their OOP vulnerability, and not prevent their collapse. Recently, in 2016 after the Central Italy Earthquake similar damages were observed. Cracking and/or collapse of the facade masonry infill panels (usually at the lower stories). Reports of local damage in column members adjacent to the damage panels were also presented [26,51]. Some earthquake evidences described by several authors, which enanced the high number of infill masonry walls damaged and/or collapsed in other events such as the L'Aquila (Italy) earthquake in 2009 [76], the Gorkha (Nepal) earthquake in 2015 [10,35,75] for example.

Over the literature, it can be found test campaigns that were carried to study and characterize the infill panel OOP behaviour that fill steel and RC frames considering and not the interaction with the in-plane (IP) loading demand $[4,11,13,16,17,27,32,31,36$, $38,37,40,52,56,58,61,60,66,73]$. Some of the test campaigns were carried out through shaking table tests of simple IM panels or scaled infilled RC structures [15,21,45,46,48,69,71,78]. Some other numerical works were carried out during the last years with the goal of simulate the infill masonry walls non-linear seismic behaviour, such as IP and OOP [6-8,30,34,43,63,68].

The main aim of this manuscript is to present a systematic review of experimental tests that were performed to study the infill walls OOP behaviour. It will be pointed out the open challenges that are still lacking a deeper research and discussion. A systematic review methodology will be detailed and the list from the final group of works that will be studied within the framework of this manuscript will be presented. Similar databases were developed by different authors in the field mechanical modelling of existing masonry assemblages and earthquake performance of infilled frames, among others $[9,44]$. With this systematic review it was collected the following information from each parameter: panel geometries, slenderness, aspect ratio, masonry 


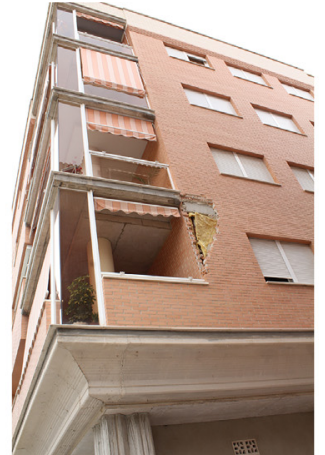

a)

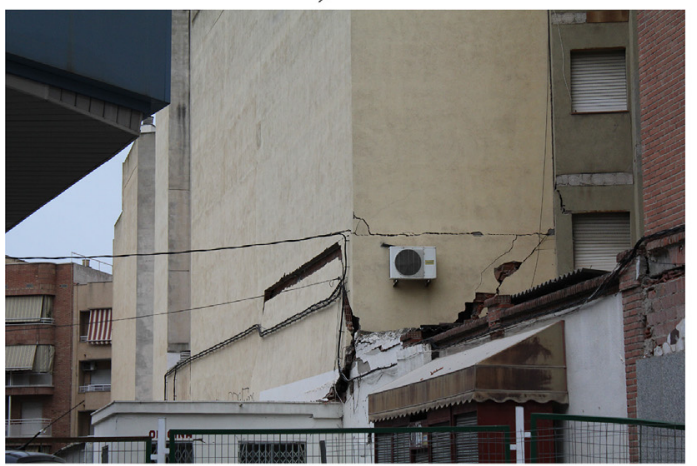

c)

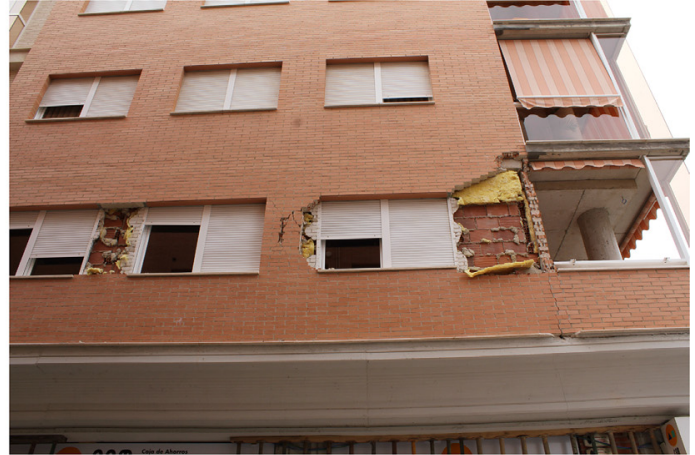

b)

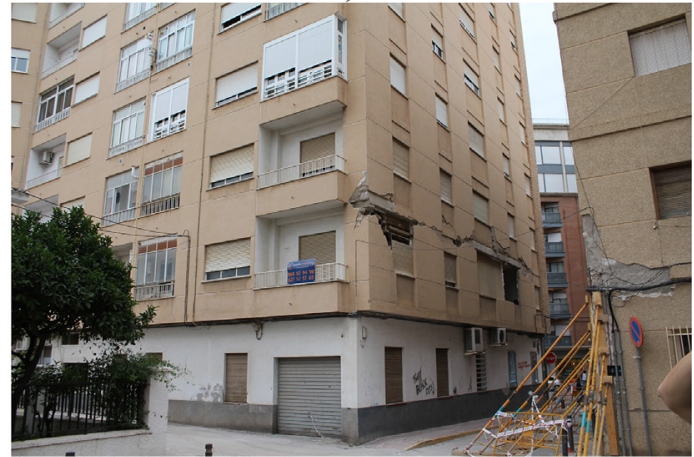

d)

Fig. 1. Examples of infill masonry walls collapses after the Lorca, Spain earthquake in 2011.

compressive strength, percentage of voids, mortar compressive strength, flexural strength, axial load, openings, previous IP damage and retrofit solutions in the OOP performance and capacity. Discussion regarding the effects of each parameter and the conclusions obtained by the different authors will be addresses throughout the manuscript. Additionally, a brief discussion regarding the different strategies available to retrofit the infill masonry walls will be presented.

\section{Systematic review methodology}

\subsection{Selection criteria}

Throughout the last five decades several efforts were carried out to characterize the infill panels OOP behaviour. From quasi-static monotonic/cyclic until shake table tests on infilled frames, the main goal was to characterize the expected seismic performance of these elements when subjected to OOP loadings or combined IP-OOP ones. Inspired in the works developed by Higgins and Green [42] and Cadório et al. [12] in the field of clinic, a systematic review methodology was used to filter the most relevant and complete works developed concerning the infill masonry walls OOP tests. The systematic review methodology can refine the literature by using explicit, rigorous, and reproducible methods to identify, critically appraise, and synthesize the best evidence from a specific subject. This methodology allows to refine the source of specific topics and better assess the influence of certain variables in the scope of a research work, which can be useful in the field of structural engineering research to analyse the available experimental data, mainly in specific topics with reduced amount of data.

Based on that, this methodology started with a comprehensive literature search that was conducted on four electronic indexing databases: Web of Knowledge, Science Direct, Civil Engineering database (ASCE) and Scopus. This search occurred between January and October 2017. The following terms were entered into the databases consulted: masonry infill test; out-of-plane masonry infill; cyclic tests masonry infill; shake table tests masonry infill and masonry infill out-of-plane cyclic behaviour.

\subsection{Study selection}

After retrieved, the records were combined using End Note (version Desktop X8) and the duplicates were removed. At this point, titles and abstracts of the remaining records were screened to find relevant articles. The papers were selected by the authors based on the set selection criteria. For instance, a timeline was set and only studies published between 1960 and 2017 were selected. Papers whose titles were not about infill masonry experimental tests were excluded. Disagreements between the review authors were solved by discussion until consensus was reached. The full text pertaining to the relevant titles/abstracts was read carefully. Those that met the established eligibility criteria were included in the final set of data. In some cases, further information about the relevant studies was needed and therefore the correspondent authors were contacted. All review authors agreed on which studies could contribute positively to the present review and the final set of data was confirmed. Numerical modelling research works were excluded due to the focus of the present study. Also tests of RC building structures (shake-table and pseudo-dynamic tests) were excluded.

Additional relevant records $(\mathrm{PhD}$ thesis and technical research reports) were collected, due to their high citation score and to the novelty of the work on that times. In fact, it was considered relevant to consider these works due to the high valuable information regarding the tests, material and mechanical properties, test results and other relevant information concerning the test setup and loading protocol.

A complete database search combined with other sources of record retrieval resulted in the identification of 990 documents. Following the removal of duplicates, 533 papers remained to be 
screened. From these, only 97 were recognized as relevant to the question of interest. Some articles were excluded in this phase, due to publication form, i.e., technical notes or similar reports $(n=7)$, insufficient information of the test campaign $(n=16)$, tests of unreinforced masonry walls $(n=3)$, studies of combined experimental and numerical simulation of the infill masonry walls OOP behaviour $(n=3)$, as illustrated in Fig. 2 .

\subsection{Data extraction, quality assessment and data synthesis}

In an attempt to understand the cause of variability in the experimental tests of infill masonry walls when subjected to OOP loadings, several variables and information were extracted from the final set of records, namely:

- Global information: geometric characteristics (panel height $\mathrm{H}_{\mathrm{p}}$, width $-\mathrm{W}_{\mathrm{p}}$ and thickness $\mathrm{t}$ ), number of tests; masonry units; type of test; type of frame; frame details (design and drawings); test setup; OOP loading condition; retrofit strategy; gravity loads; previous IP drift level; panel mass;

- Material properties: type of mortar; mortar compressive $\left(f_{m o}\right)$ and flexural strength $\left(\mathrm{f}_{\mathrm{t}, \mathrm{mo}}\right)$, masonry unit percentage of voids (\% voids), masonry unit compressive strength parallel $\left(\mathrm{f}_{\text {unit,b,parallel }}\right)$ and perpendicular $\left(\mathrm{f}_{\text {unit,b,perpendicular }}\right)$ to the holes;

- Mechanical Characterization: masonry wallets compressive strength $\left(\mathrm{f}_{\mathrm{m}}\right)$, elasticity modulus $\left(\mathrm{E}_{\mathrm{m}}\right)$, flexural strength parallel

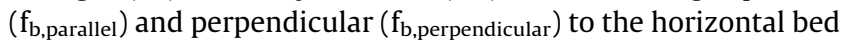
joints, bond-shear strength and diagonal tensile compression strength $\left(\mathrm{f}_{\mathrm{t}}\right)$;

- Test Results: the information extracted from the test results is illustrated in Fig. 3; basically consists in the collection from the force-displacement curve of the following parameters: maximum strength coordinate $\left(\mathrm{F}_{\max }, \mathrm{d}_{\mathrm{fmax}}-\mathrm{star}\right), 80 \%$ of the maximum strength (after peak load: $F_{0.8 \text { Fmax }}, \mathrm{d}_{0.8 \text { Fmax }}-$ pentagon), ultimate strength coordinated which was defined by the authors $\left(\mathrm{F}_{\mathrm{ult}}, \mathrm{d}_{\mathrm{ult}}\right.$-rotated square), $15 \%$ of the maximum

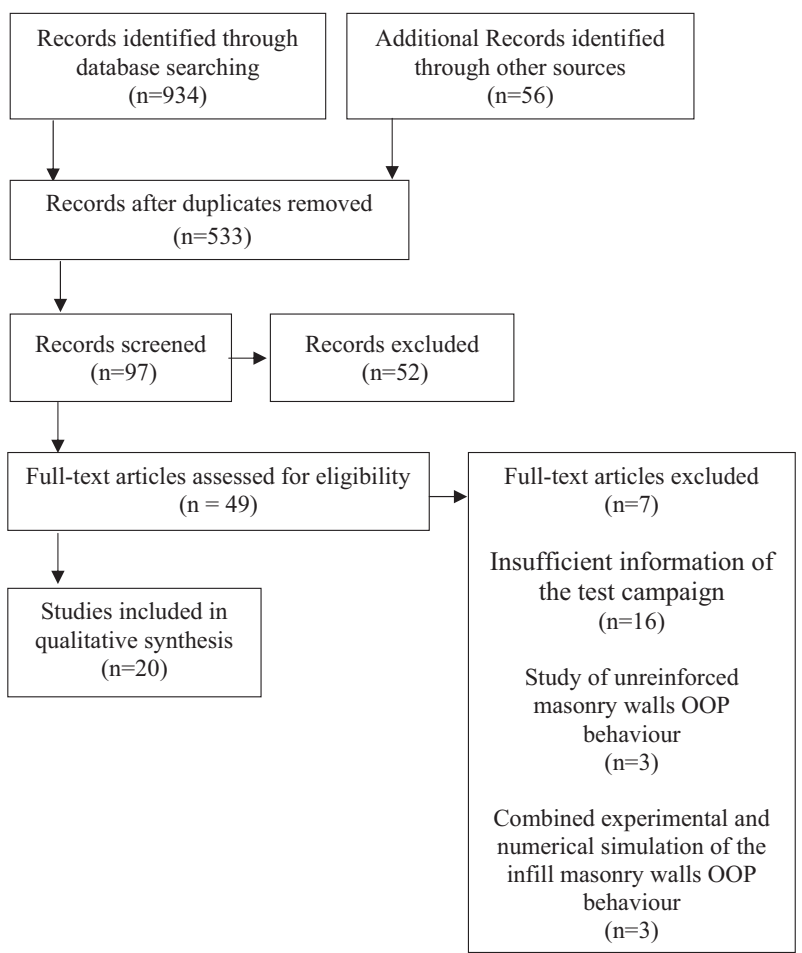

Fig. 2. Systematic review methodology: Selection of studies. strength coordinate (before peak load: $\mathrm{F}_{0.15 \mathrm{Fmax}}, \mathrm{d}_{0.15 \mathrm{Fmax}}-$ triangle), $30 \%$ of the maximum strength coordinate (before peak load: $F_{0.30 F m a x}, d_{0.30 F m a x}-$ circle), secant stiffness $\left(K_{\text {sec }}\right)$, secant stiffness at $0.8 \mathrm{~F}_{\max }\left(\mathrm{K}_{0.8 \mathrm{Fmax}}\right.$ - which will peak the pentagon coordinate); ultimate secant stiffness $\left(\mathrm{K}_{\mathrm{Fult}}-\right.$ which will peak the rotated square coordinate); cracking coordinate (corresponding to the appearance of the first major cracking during the test - information provided by the authors), accumulative energy dissipation and damages observed during the test.

Data extraction was independently analyzed and it was defined whether the data fulfilled accuracy requirements. Overall, evidence from the selected studies was summarized and hypotheses/ explanations derived. A qualitative analysis was employed, as it was considered the most appropriate method to address the question of interest, while attending the heterogeneity of studies concerning the design and outcome measures.

\subsection{Final database}

A complete database search combined with other sources of record retrieval resulted in the identification of 20 research works, summarized in Table 1. Appraisal of scale items followed a dichotomous response format (present/absent), where the presence of each criterion was awarded one point and the absence zero points. A maximum score of 11 points can be reached with this methodology.

\section{Global overview of the literature' infill masonry walls OOP tests}

\subsection{Background}

Over the literature different types of test were adopted to study the infill masonry walls OOP behaviour, quasi-static tests (monotonic or cyclic), pseudo-dynamic tests and shake-table tests. In order to analyse the panel behaviour, only one-frame, one-storey specimens were considered for this systematic review as described in Section 2.2. From the database it was found a total of 138 tests: $67 \%$ of those monotonic, $23 \%$ cyclic and finally $10 \%$ shake-table tests (Fig. 4a). Regarding the specimen scale, $76 \%$ were full-scale tests and the remaining scales used were $1: 1.5,1: 2$ and $1: 3$ (Fig. 4b). The majority of the specimens tested were as-built infill masonry walls (72\%) and the remaining ones were on retrofitted panels (21\%) and on panels with bed joints reinforcement (7\%), like

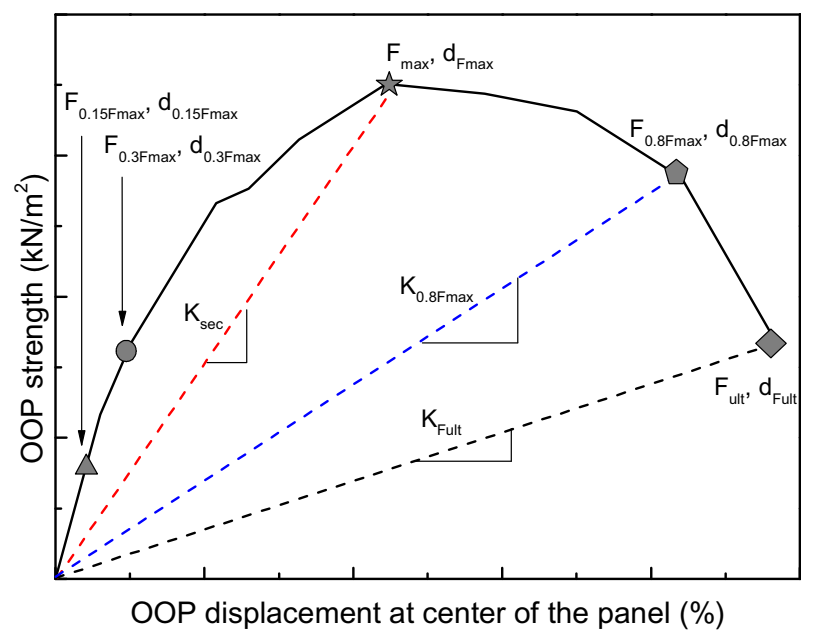

Fig. 3. Data information gathered from the force-displacement results. 


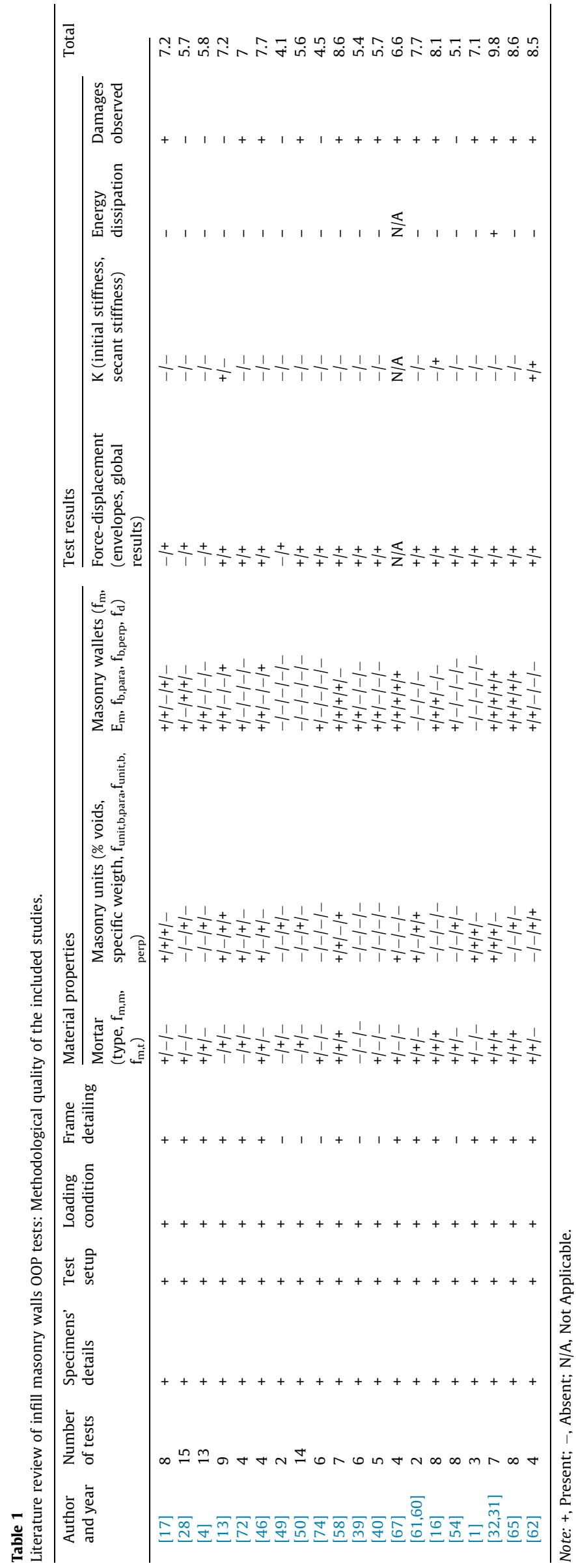

presented in the Fig. 4c. It was observed that most part of the walls tested were surrounded by a RC frame (Fig. 4d).

\subsection{OOP loading application strategies and protocol}

Regarding the quasi-static tests, different loading protocols were considered all over the literature. In a real seismic scenario the panel is subjected to combined and multiple loadings, such as IP-OOP lateral loadings combined with gravity loads (applied by the top structural frame members). The simulation of this combined amount of loadings is very difficult to achieve due to the test setup complexity. Due to this, $42 \%$ of the tests consisted on pure OOP tests. Combined IP-OOP tests compose $10 \%$ of the literature experimental tests and the loading protocol id divided in two stages, namely: i) IP test to impose some certain damage to the wall; ii) application of OOP load on the damaged infill panel. These tests are very important, since the infill masonry walls performance was very affected by the existence of previous damage. This topic will be deeply addressed in Section $4.22 \%$ of the tests were composed by IP-OOP tests combined with the application of gravity load. Different strategies were adopted by the authors regarding the gravity loading application. Some authors applied the gravity load directly in the top of the upper beam, some others applied in the top of the columns. From the literature analyse, the strategy adopted to apply the gravity load is not totally clear, due to uncertainties associated to the distribution of the loading, which can be transferred to the wall and and/or to the columns. Also the complicity of the test setup, as already mentioned, is an important limitation. In a real scenario, the wall is subjected to certain gravity load (infill panel axial load), imposed by the short and long term deformation of the top beam/slab. Finally, $15 \%$ of the tests were OOP tests combined with gravity load and $11 \%$ IP-OOP tests without gravity load (Fig. 5a).

One of the major goals of the infill masonry walls OOP tests is to reproduce the seismic actions effects. Due to the distributed infill masonry wall mass, the tests setups used at laboratory conditions were conceived in order to mobilize the entire panel. Quasi-static tests were performed by different authors by applying distributed or local forces that mobilize the OOP response of the panel.

Different methodologies can be adopted to apply OOP loadings, starting from water bags [55] or airbags [38,37]. Griffith et al. $[38,37]$ tested unreinforced masonry walls by applying OOP pressure loadings through the entire specimen. Double-leaf airbags were used, one in each façade of the specimen to perform complete cyclic, instead of the load-unload inherent to the adoption only for the one-layer airbag. One of the disadvantages associated to the use of the double-leaf airbags is the impossibility of following the damages' evolution throughout the test; the synchronization between the two airbag layers is also considered a difficulty. The use of local loads (four or eight application points) applied by hydraulic actuators is commonly adopted to overcome the difficulties inherent to the complexity of test setups that guarantee the entire mobilization of the panel. However, several authors indicated that one disadvantage of this approach is that it can introduce or modify the expected infill masonry wall failure mode when subjected to a real earthquake.

The use of airbags revealed to be very effective as proved by the recent by the works developed in the masonry field [24,25,36-38]. As can be observed in Fig. 5b, about ninety OOP tests were carried out within the application of the OOP loading with airbags.

\subsection{Specimens dimensions}

Different masonry units were selected for the OOP tests, which is basically due to the option of use the most common masonry unit of each country. Concrete and clay units are the most common 


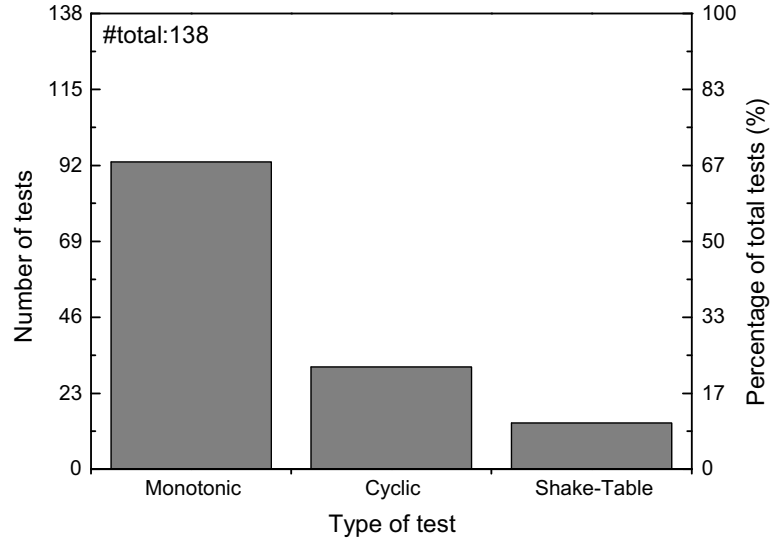

a)

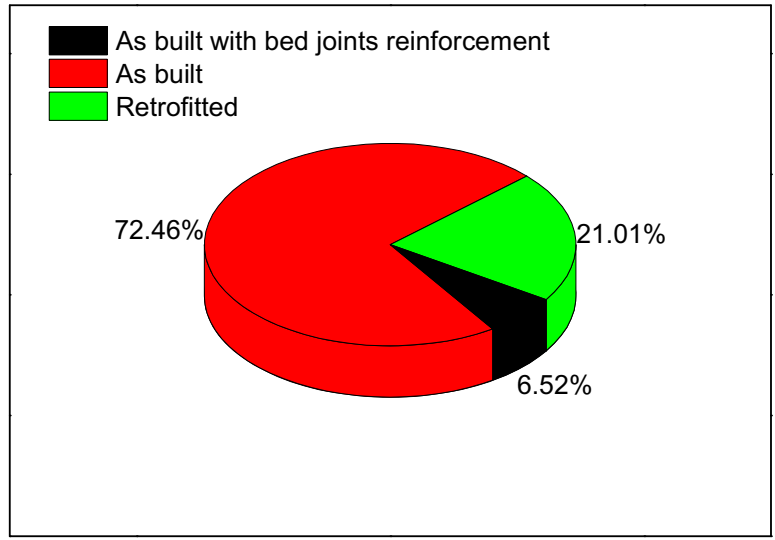

c)

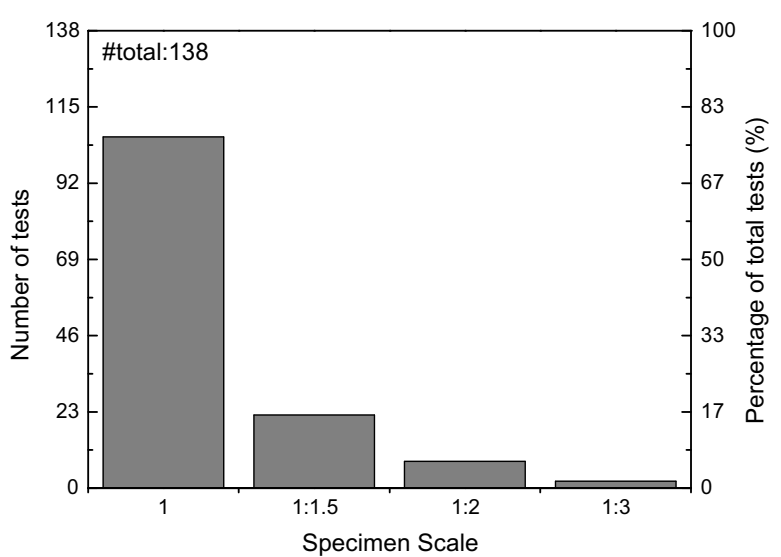

b)

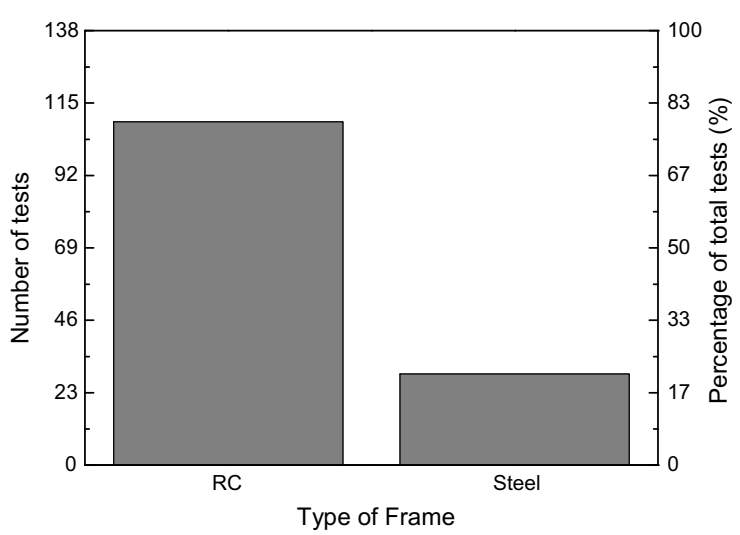

d)

Fig. 4. Global overview results: a) Type of test; b) Specimen' scale; c) Specimen' details; and d) Type of frame.

material of the masonry units used. Some authors highlight the possibility of obtaining different failure mechanisms or behaviour of the panel when subjected to OOP loadings when it is scaled masonry units. The majority of the tests were related to infill panels constructed with horizontal clay hollow bricks (HCHB) and solid clay bricks (SCB), respectively $31 \%$ and $29 \%$. The remaining ones were made with vertical hollow concrete blocks (VHCB), concrete solid brick (CSB) and clay vertical hollow brick (CVHB), respectively $16 \%, 10 \%$ and $14 \%$ (Fig $6 a$ ). The geometric dimensions of the specimens were analyzed, and it was found a large variability (Fig 6b). However, it was observed that the majority of the tests has larger width than height. Only one specimen was found to have a square dimension. The design of the panel area $\left(A_{p}\right)$ appears to be not direct related with the thickness as can be observed in Fig. 6c. The empirical Eq. (1) is suggested to follow the relationship between the thickness and the panel area of the specimens analyzed. On the other hand, it can be observed a direct proportionality between the panel aspect ratio and the panel slenderness (Fig. 6d) and can be given by Eq. (2). However, due to the large dispersion of the results, the accuracy of the empirical equation proposed are lower with $\mathrm{R}^{2}=0.71$ and $\mathrm{R}^{2}=0.51$. If some outliers were excluded the accuracy will certainly increase.

$t=0.1009 \times A_{p}^{0.4497}$

$\frac{H_{p}}{t}=22.101 \times\left(\frac{H_{p}}{W_{p}}\right)^{0.6318}$

\section{As-built infill masonry walls OOP behaviour}

\subsection{Effect of RC frame type and detailling}

Different RC frame detailing were found over the literature, some authors assumed that the design of the frame was according to each national standard considering the expected seismic action and high ducility requirements. Special attention was provided to the columns, specially to the top and bottom part which are the regions were it is expected to develop the plastic hinge $[16,39,40]$. Some other authors pointed that no special attention was provided to the RC frame detailing in terms of seismic design, since a representative part of the RC buildings were not designed considering the seismic actions or with very low requirements, with reduced amount of transversal reinforcement, poor beamcolumn joint detailing and with insufficient anchorage length. For example, Furtado et al. [29] developed a statistical study of the Portuguese RC buildings and found that more than 50\% of the buildings at that time were designed with codes that consider very low and insuficient seismic provisions. As can be observed in Fig. $7 \mathrm{a}, 40 \%$ of the RC frames used to test the OOP capacity of the infill panels were designed with high ducitility demand, $25 \%$ with low ductility. The remaining 35\% of the frames design approach and criteria were not provided by the authors. In Fig. 7b is plotted the maximum strength capacity of 32 infill panels without previous IP damage. The panels were built in RC frames with high and low ductility demands. Due to the large number of variables among the tests, such as panel aspect ratio, masonry units, 


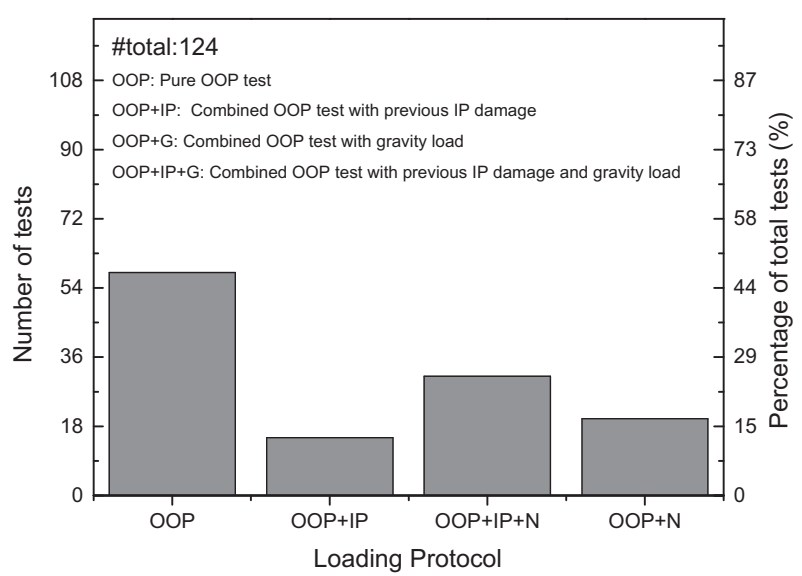

a)

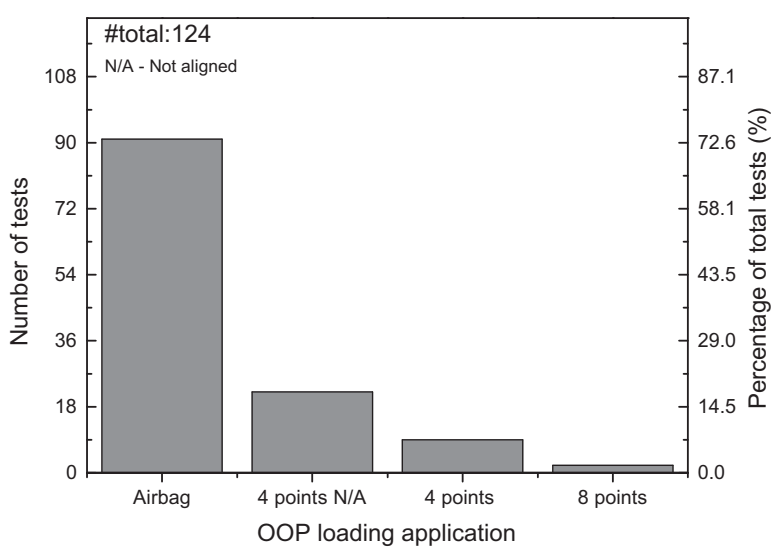

b)

Fig. 5. Global overview results: a) loading protocol; b) OOP loading application strategy.

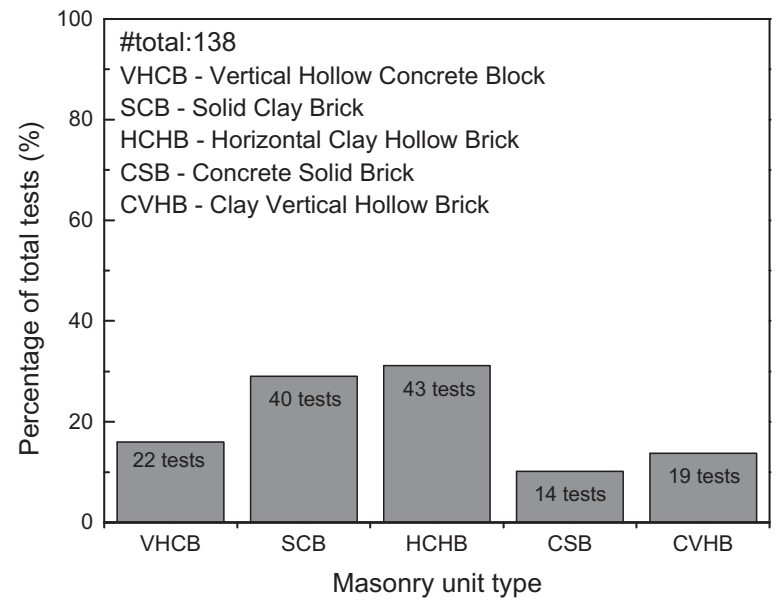

a)

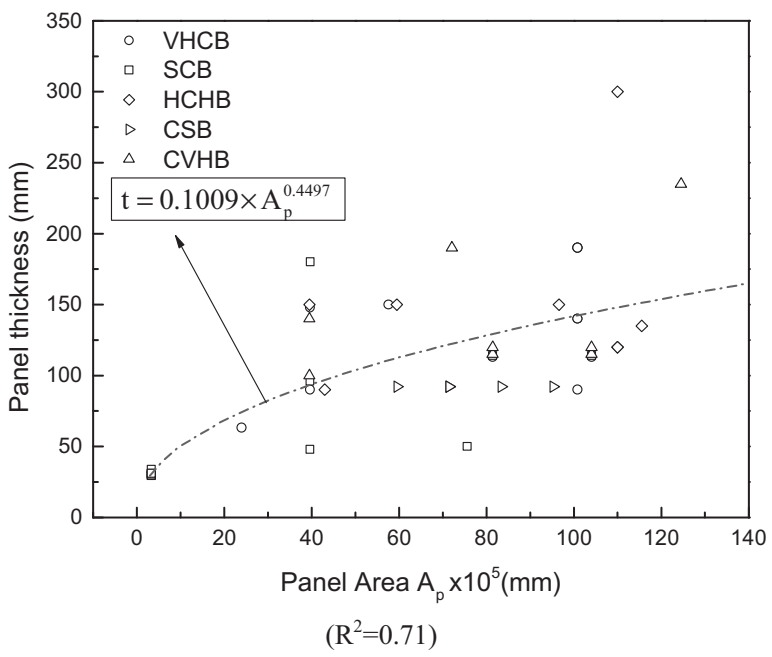

c)

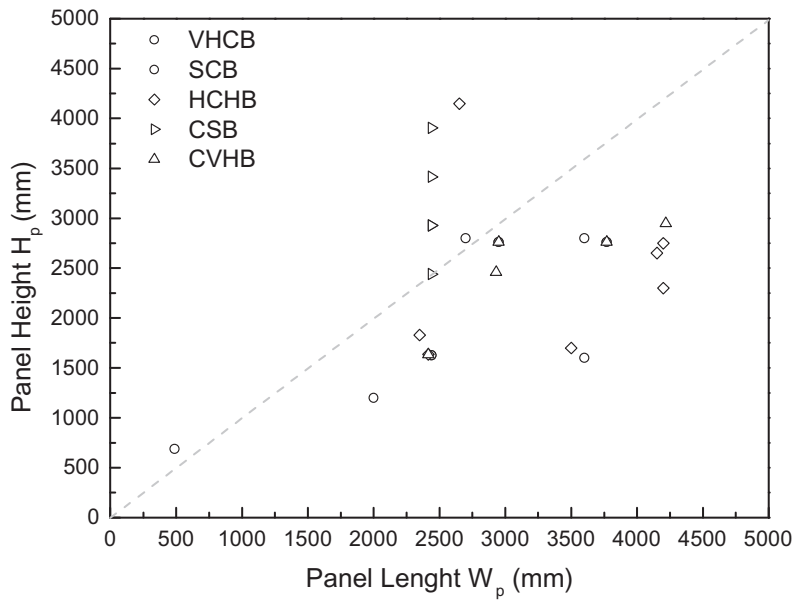

b)

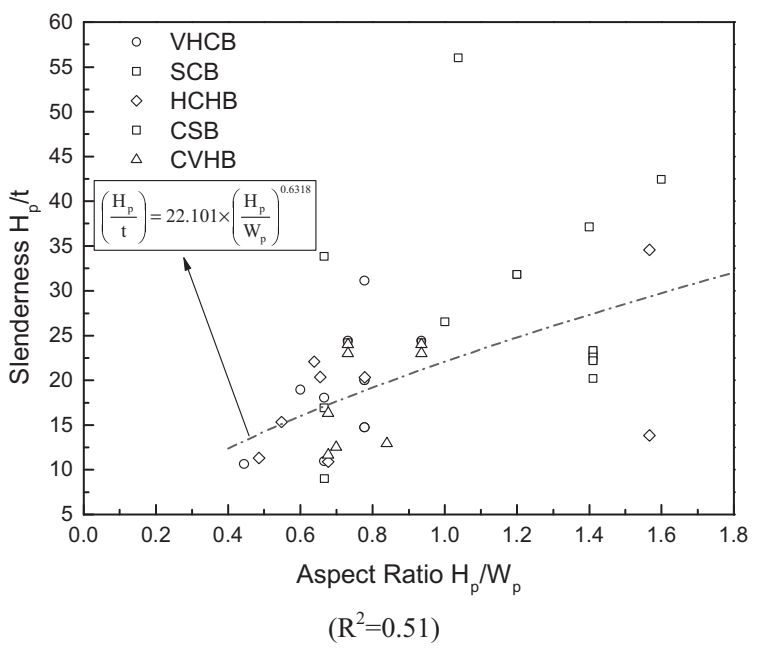

d)

Fig. 6. Global overview results: a) masonry unit type; b) panel height vs panel length; c) panel area vs panel thickness; d) aspect ratio vs slenderness.

masonry mechanical properties and others that will be discussed throughout this manuscript, no tendencies can be achieved. From the point of view of pure OOP tests, the frame detailing cannot play an important role since the frame is not being tested. From the literature review, the frame can influence and affect the OOP performance of the panel in terms of the adhesion conditions provided by the concrete-bed joints mortar-masonry. Different observations can be addressed to combined IP and OOP tests, since the damage of the panel caused by IP depends of the global infilled frame behaviour. For example, an infilled RC frame designed 
according to standards with high seismic demands will have a better performance when subjected to lateral loadings, which probably leads to lower levels of damages in the panels. In section 5 it will be pointed that low levels of previous damage leads to a better OOP performance. Thus, it should be pointed that in the case a real earthquake scenario, the RC frame reinforcement detailing can have an important contribution for the infill OOP behaviour.

\subsection{Effect of geometric dimensions and mechanical properties}

The influence of the geometric global dimensions (panel aspect ratio and slenderness) and the mechanical properties in the panel OOP maximum strength was assessed. The results were divided according to the masonry unit group (HCHB, SCB, VHCB, CSB and CVHB) used and only tests without gravity load and openings were analyzed. Some tendencies were observed regarding the influence of the panel aspect ratio, namely it is observed a decrease of the panel maximum OOP strength with the increase of the aspect ratio (Fig. 8a). Eq. (3) was proposed to correlate the panel aspect ratio and the corresponding maximum strength. The accuracy of the prediction equation is reduced due to the large variability observed $\left(R^{2}=0.72\right)$. However, the same cannot not be observed for the individual groups of masonry units. A global tendency of the increase of the maximum OOP strength with the increase of the panel slenderness is observed (Fig. 8b) as well. A large dispersion of results was found for the Group CVHB and SCB. Two empirical equations are provided for the tendency observed for groups HCHB and VHCB respectively Eqs. (4) and (5). The reduced amount of data containing information regarding the percentage of voids limited the analysis of this effect in the panel OOP capacity. Besides the reduced number of data (12 elements), it can be observed that with the increase of the percentage of voids the panel maximum OOP strength is lower, which is due to the panel incapacity to develop arching mechanism and to the crushing of bricks during this mechanism (Fig. 8c).

$F_{\max }=18.233 \times\left(\frac{H_{p}}{W_{p}}\right)^{-1.479}$

$F_{\max , V H C B}=17.559 \times e^{-0.023 \times\left(H_{p} / t\right)}$

$F_{\max , H C H B}=26.315-2.126 \times\left(\frac{H_{p}}{t}\right)+0.0533 \times\left(\frac{H_{p}}{t}\right)^{2}$

$F_{\max }=3.3626 \times(\% \text { voids })^{-2.085}$

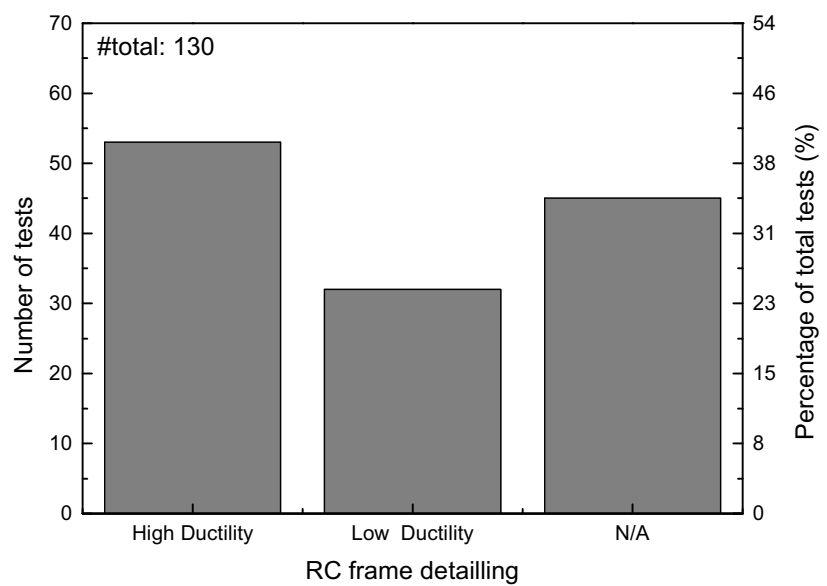

a)
The masonry properties play an important role in the panel OOP capacity. For example, as expected the maximum OOP strength increase with the increment of the masonry compressive strength, in particular the panels made with SCB reached a good linearity correlation that follow the Eq. (7) with $\mathrm{R}^{2}=0.91$ (Fig. 8d). Eq. (7) was proposed taking into account all the data except the group VHCB results. An increase of the masonry compressive strength from $10 \mathrm{MPa}$ to $25 \mathrm{MPa}$ resulted on an increment of $200 \%$ of the panel maximum OOP strength. The same was not observed for the panels made with VHCB. The masonry flexural strength parallel to the bed joints varied slightly, between 0.1 and $0.55 \mathrm{MPa}$ (Fig. 8e), however this variation increased the OOP strength capacity of the panel around $200 \%$. The Eq. (8) was suggested with good correlation $\mathrm{R}^{2}=0.80$. The same was observed regarding the influence of the flexural strength perpendicular to the horizontal bed joints (Fig. 8f). Similarly, Eq. (9) was suggested to predict the panel maximum OOP strength based on the perpendicular flexural strength with $\mathrm{R}^{2}=0.83$. The panels made with VHCB appears to have no relationship with the panel aspect ratio, compressive and flexural strength (parallel to the horizontal bed joints). Only few authors provided information regarding the masonry units' compressive strength and it was not possible to assess the effect of this parameter. There is clear need of additional data from test campaigns. With the reduced amount of data available it is not possible to achieve further conclusions.

$$
\begin{aligned}
& F_{\max }=3.5372+1.7632 f_{m}-0.0106 f_{m}^{2} \\
& F_{\max }=3.2365+76.34 \times f_{b, \text { para }} \\
& F_{\max }=-12.188+48.976 \times f_{b, \text { perp }}-9.4575 \times f_{b, \text { perp }}^{2}
\end{aligned}
$$

The relationship between the OOP drift at the maximum strength $\left(\mathrm{F}_{\max }\right)$ and, $0.8 \mathrm{~F}_{\max }$ and $\mathrm{F}_{\text {ult }}$ was plotted in Fig. 9a and $\mathrm{b}$ respectively. For the last two parameters it was performed the ratio between the corresponding drift and the $\mathrm{OOP}_{\mathrm{Fmax}}$. It is observed that the drift variation at $0.8 \mathrm{~F}_{\max }$ is around $1.2-3$ times

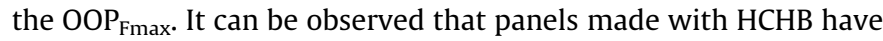
larger deformation capacity to reach larger OOP drifts after reached the maximum strength. The same is observed when it is compared

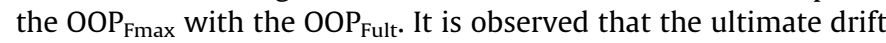
varies between 1 and 3.5 times the drift at $F_{\max }$, for panels with HCHB, 1.5-2.5 times to CSB panels and 1.1-4 times for VHCB (but the $\mathrm{OOP}_{\mathrm{Fmax}}$ is lower compared with the other panels). The relative stiffness was calculated based on the secant stiffness for three different levels: $0.3 \mathrm{~F}_{\max }, 0.6 \mathrm{~F}_{\max }$ and $\mathrm{F}_{\max }$. From the results

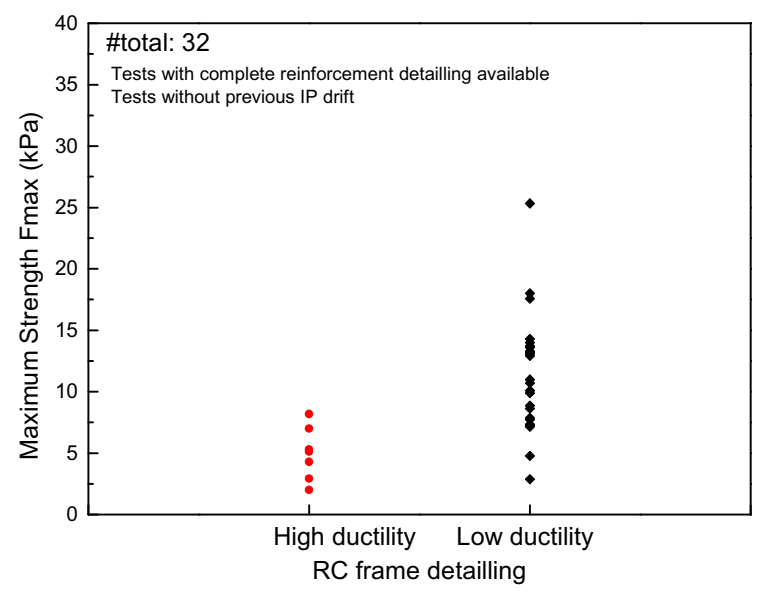

b)

Fig. 7. As built specimens' results: a) RC frame detailing; b) Maximum strength capacity according to RC frame detailling. 


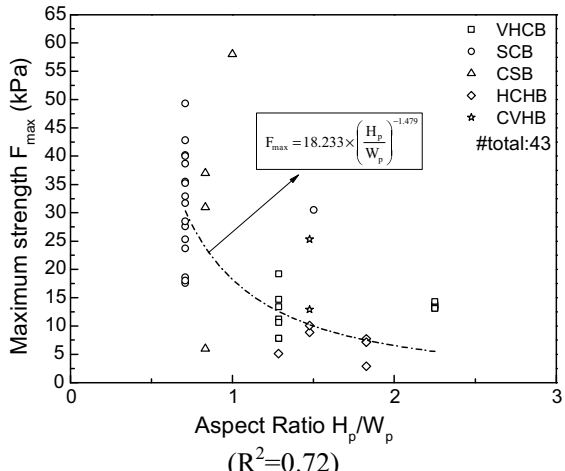

a)

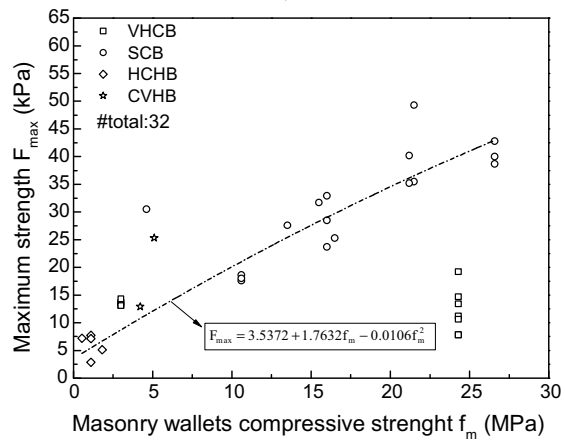

$\left(\mathrm{R}^{2}=0.91\right)$

d)

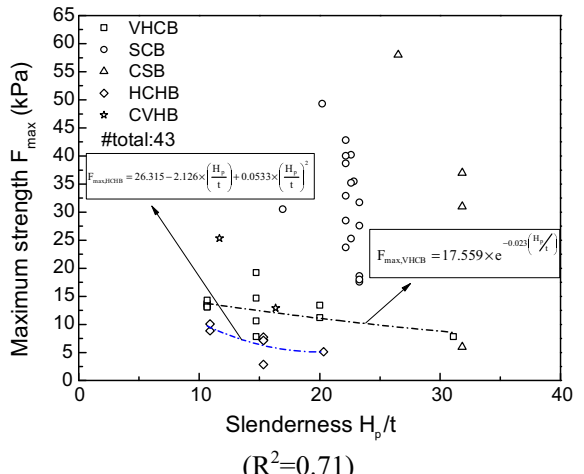

b)

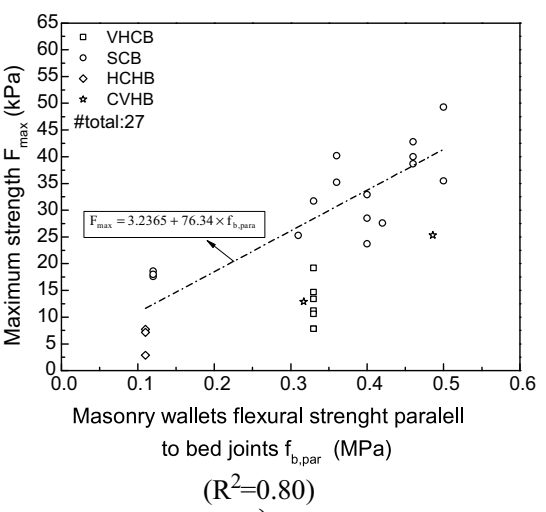

e)

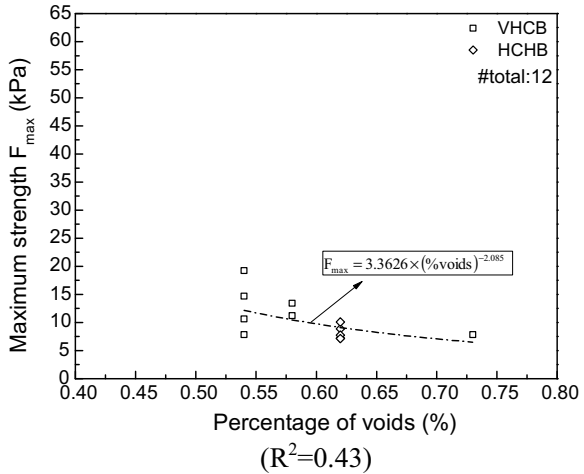

c)

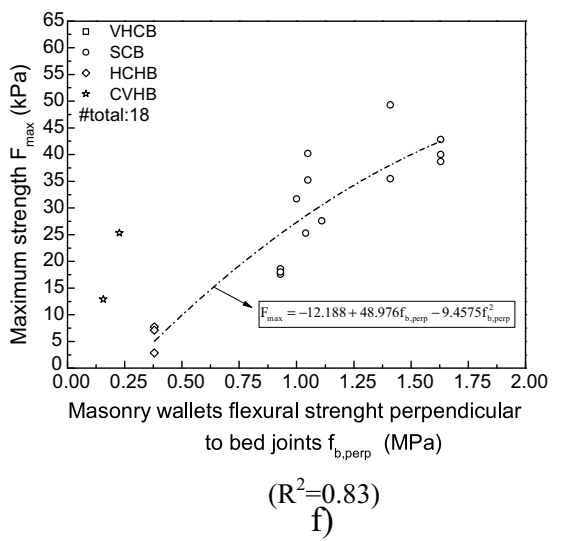

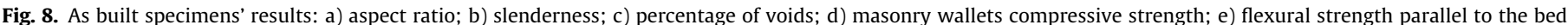
joints; and f) perpendicular to the bed joints.

(Fig. 9c) it can be observed a large decrease for OOP drifts less than $0.5 \%$. Almost $40 \%$ of the data decreased more than $50 \%$ of the specimen stiffness. It is observed a variation between 10 and $40 \%$ of the specimen stiffness for OOP drifts between 0.5 and $5 \%$. It is observed that larger OOP drift were achieved for panels with larger aspect ratio and lower panel slenderness as observed in Fig. 9d and e.

\subsection{Effect of vertical dead load}

Throughout the literature, four different authors carried out OOP tests in as-built specimens considering the vertical dead load. In 1994 Angel et al. [4] tested one specimen specifically to assess the influence of the gravity load in the panel response. The load was applied in the top of the frame columns. A normalized axial stress of 0.04 was applied in each column. The authors obtained almost similar force-deflection curves between the specimen $6 c$ with and without gravity load (specimen $6 \mathrm{t}$ ). No new cracks were observed during the test. However, the vertical stress provides an increment of the specimen stiffness until the vertical stress was overcome by the OOP loading. After this, the behaviour of both specimens were not distinguished from each other. Furtado et al. $[32,31]$ studied specifically the effect of the gravity load applied in the top of the frames columns $(v=0.11)$ in the panel OOP capacity. Two specimens (Inf_01 and Inf_04) were tested considering the gravity load, being the first one subjected to a monotonic OOP loading and the second one to a cyclic load. Both were compared with the response of the reference specimen Inf_02 (cyclic OOP load without gravity load). Different responses between the specimens with and without gravity load were obtained. From the study it was observed that the both panels with gravity load (Inf_01 and Inf_04) achieved lower initial stiffness, higher strength degradation (Fig. 10a). However, different impact in the maximum strength was observed, since panel Inf_01 increased about 5\% and Inf_04 decreased $35 \%$. This can be explained by the fact that Inf_01 was subjected to a monotonic OOP tests instead of the reference one that was subjected to a cyclic loading. Furtado et al. [33] evaluated also the effect of the gravity load in the panel OOP frequency. The author found a variation of $15 \%$ with the gravity load increment applied in the top of the columns (Fig. 10b). Cracking pattern was also affected by the gravity load, namely the Specimen Inf_02 was characterized by a trilinear cracking instead of the Specimens Inf_01 and Inf_04 that obtained a vertical cracking at the middle of the panel plus the detachment from the top and bottom beam.

The works performed by Varela-Rivera et al. [74] and Calvi and Bolognini [13] were not carried with the aim of evaluate the effect of the gravity load in the infill masonry wall OOP performance. From these tests, as described in section 3.2, Varela-Rivera et al. [74] was the only work where the gravity load was distributed along the top beam. Due to the reduced number of data it cannot be achieved solid conclusions regarding the effect of this variable. However, it was observed that specimen $6 \mathrm{t}$ reached less than $50 \%$ of the reference specimen maximum strength.

\subsection{Effect of openings and support condition}

The effect of the openings in the panel OOP response was only evaluated with the data from 5 tests. Dawe and Seah [17] tested an infill masonry wall with a central opening from which concluded that no significant decrease of the panel maximum strength was observed, however some differences occurred during the post-peak phase. The authors concluded that a central opening destroyed the ability of the central strips to support the load and the post-peak phase ductility reduced. The OOP drift 


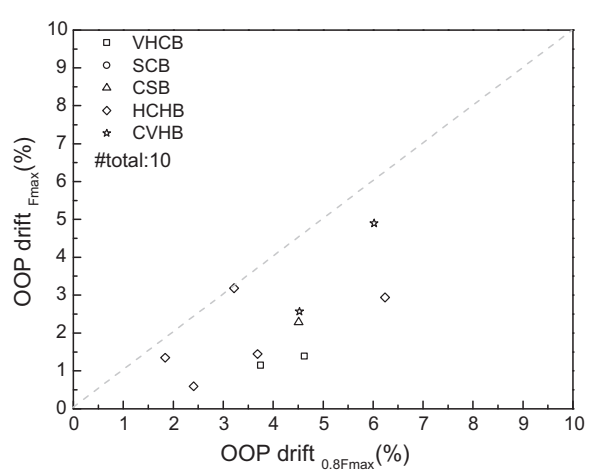

a)

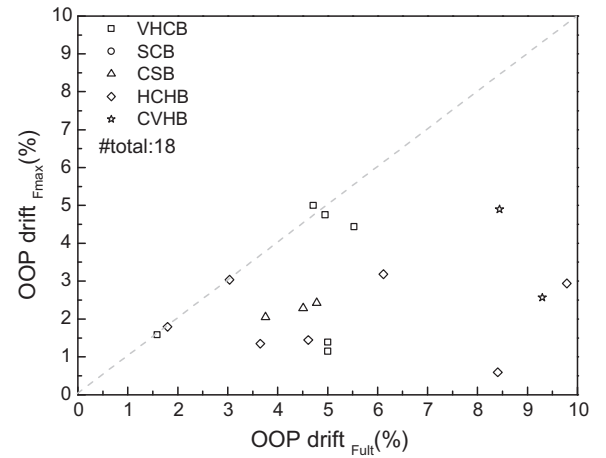

b)

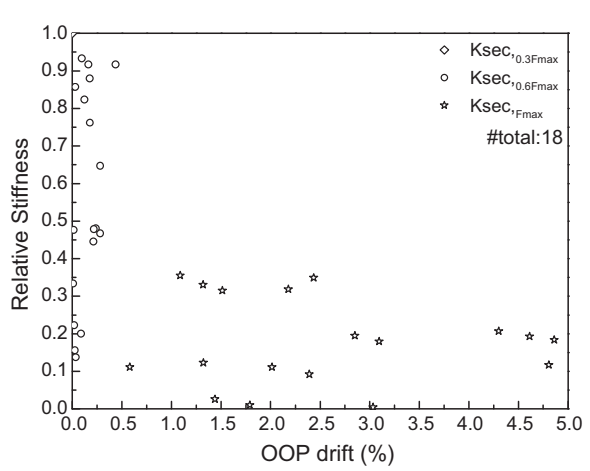

c)

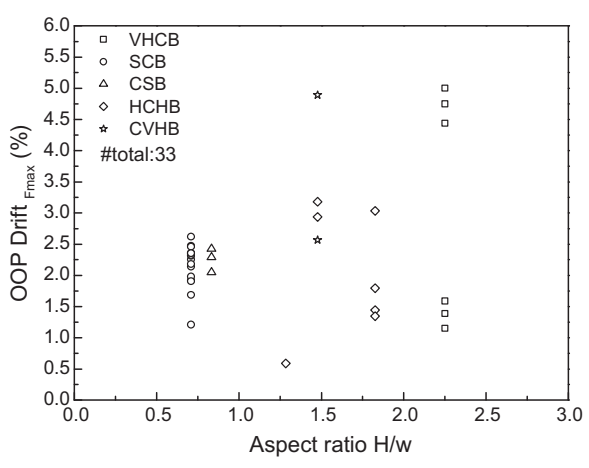

e)

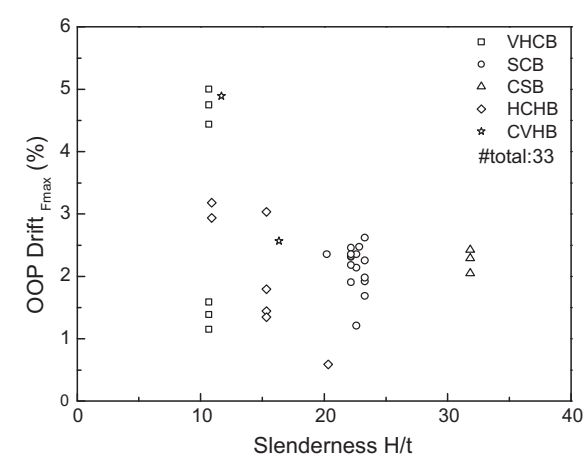

f)

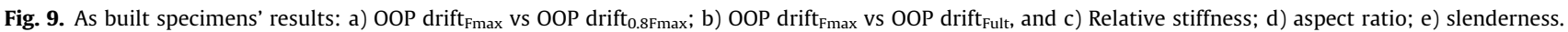

corresponding to the maximum strength was lower for the specimen with the central opening. It was concluded by the authors that an opening with small dimensions does not affect the arching strength considerably. Hak et al. [40] tested two different specimens partially filled, namely specimen TA4 with a central opening and TA5 with a vertical infill stripe configuration. The test TA4 was subjected first to an IP cyclic test until a maximum drift of $1 \%$ and after that was subjected to OOP half-cyclic loads applied by four points on each part of the infill. The specimen TA5 was only subjected to half-cyclic OOP loadings applied in eight central points was aimed to reproduce vertical single-bending. Due to the large influence of the previous damage and to the not usual configuration of the wall TA5 no significant conclusions were drawn by the authors regarding the openings effect. Preti et al. $[59,61,60]$ tested one specimen with central opening and used engineered sliding joints to improve the capacity of the panel when subjected to IP and OOP loading demands. Due to the use of the sliding joints the panel will behave in a different manner than the traditional infill masonry walls. Due to that, this test will be discussed in section 6. Finally, Akhoundi et al. [1] carried out a OOP test of a scaled single infill masonry wall with a central opening. It was observed by the authors, that the panel collapsed for low OOP displacements. The maximum deformation achieved was about $1 / 4$ of the one obtained by the reference specimen. It was also observed a reduction of about $13 \%$ of panel initial stiffness (similarly to the percentage of the opening area). Only one test was found in the literature with the aim of assess the impact of the reduction of the panel width support in the OOP capacity. Furtado et al. [32,31], carried out an OOP tests to a panel partially supported in the bottom beam. The panel was built with $2 / 3$ of the panel width supported in the bottom beam (Fig. 11a). Many differences were observed in the force-displacement response (Fig. 11b of the panel, namely: i) initial stiffness decreased 15\%; b) the maximum strength decreased $60 \%$; c) no strength degradation is observed; d) the energy dissipation capacity decreased $90 \%$. Regarding the cracking pattern it is observed similar pattern, a trilinear cracking followed by slight top detachment between the panel and the top beam (Fig. 11c).

\section{Assessment of the previous IP damage effect on the infill masonry walls OOP capacity}

\subsection{Background}

The previous damage caused by IP demands modify the infill masonry walls OOP performance, namely the strength capacity as well as the failure mechanism. Six authors studied in particular this IP-OOP interaction by performing OOP tests to panels that were firstly subjected to IP tests and consequently to different damage levels. Angel et al. [4] tested two specimens made with SCB (slenderness $=33.9$ ) that were subjected to combined IP and OOP loadings. The specimens 3 and $2 \mathrm{~b}$ were tested firstly to IP loading demand to different drift levels $(0.22 \%$ and $0.34 \%$ respectively), and after that were subjected to a monotonic OOP loading until the collapse of the panel. The reference specimen 1 was subjected only to a uniform OOP loading and reached a maximum strength of $8.18 \mathrm{kPa}$. The specimens 3 and $2 \mathrm{~b}$ achieved a maximum strength of $5.98 \mathrm{kPa}$ and $4.02 \mathrm{kPa}$ respectively which corresponds to a reduction of $27 \%$ and $51 \%$. No details regarding the failure mechanism were provided by the authors.

Calvi and Bolognini [13] tested two full-scale single panel made with HCHB with slenderness equal to 20.4, that were subjected to combined IP-OOP tests. The specimen 6 was first subjected to $0.4 \%$ IP drift and specimen 2 to $1.2 \%$. After that, both were subjected to a monotonic OOP load applied in four points. The tests were compared with the reference specimen 10 which was only tested to OOP. From the results it was observed a decrease of the OOP maximum strength of $75 \%$ and $82 \%$ respectively. No reports were 


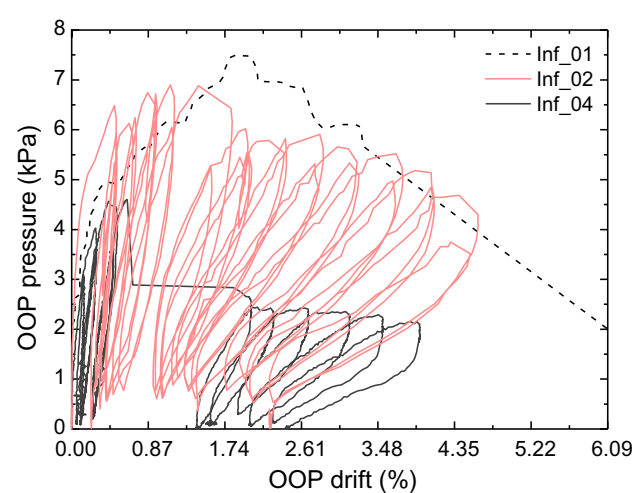

a)

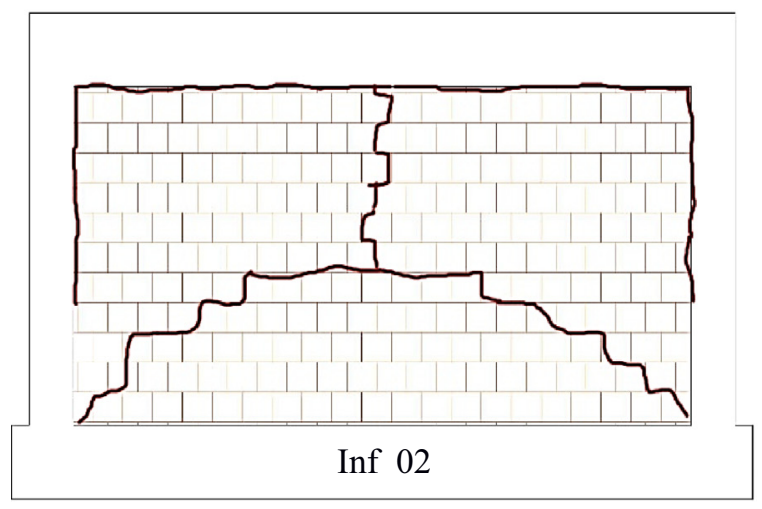

c)

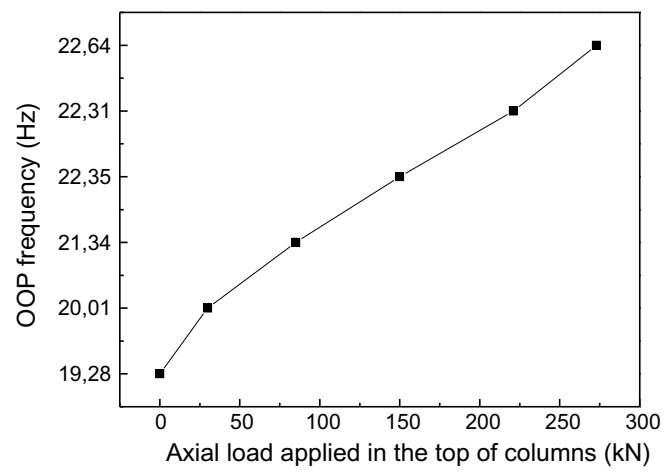

b)

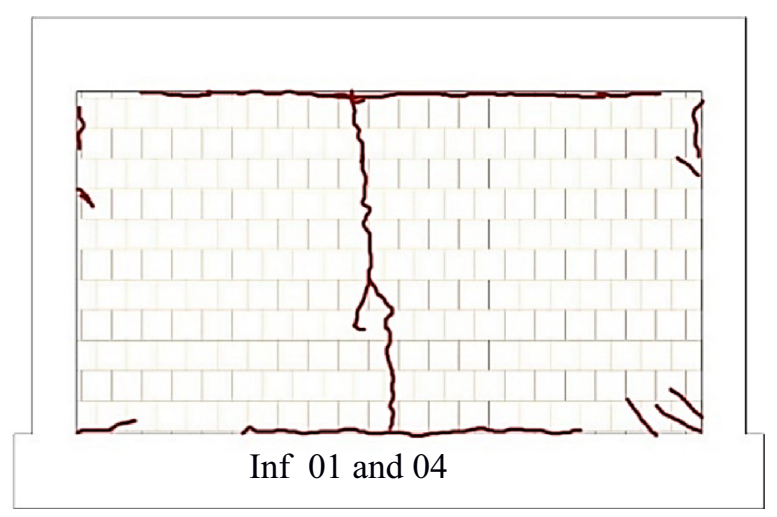

d)

Fig. 10. Gravity load effect studied by [32,31,33]: a) Force-displacement curve; b) variation of the OoP frequency with the axial load; c) and d) cracking pattern.

provided regarding the cracking pattern or failure mechanism observed. Furtado et al. [32,31] tested one full-scale double-leaf infill masonry wall made with HCHB firstly to IP cyclic loading until a maximum drift of $0.5 \%$. After that, the interior leaf was removed and the external one was tested to OOP cyclic loading. The specimen Inf_03, with slenderness equal to 15.3 , obtained $70 \%$ lower maximum OOP strength and it was observed a very fragile behaviour. The panel behaved as a rigid body behaviour during the OOP test with no visible cracks. The energy dissipation capacity of the panel reduced 95\% when compared with the reference one. Ricci et al. [62] test campaign was composed by 3 combined IPOOP tests of 2:3 scaled infill masonry walls made with HCHB with slenderness equal to 20.3. The specimen IP_OOP_L, IP_OOP_M and IP_OOP_H were subjected to $0.16 \%, 0.37 \%$ and $0.58 \%$ maximum IP drift respectively. These specimens were compared with the reference specimen OOP_4E that was not subjected to previous IP loading. The IP_OOP_M and IP_OOP_H maximum strength reduced about $53 \%$ and $74 \%$ respectively. However, unexpected result was achieved by panel IP_OOP_L which occurred an increase of the maximum strength around $6 \%$. The authors justified the result with experimental variability.

Pereira et al. [58] carried out a series of 7 tests, 1:1.5 scaled, made with HCHB with slenderness 11.3 subjected to combined IP-OOP tests. However, no specimen was subjected only to pure OOP loading and the effect of the previous IP damage in the panel response was not assessed. The main goal of the test campaign was to discuss the efficiency of different retrofit solutions. Guidi et al. [39] performed a similar study, by testing 6 full-scale panels made with HCHB and slenderness of 13.8 with different types of mortar and strengthening solutions. The effect of the previous IP damage in the panel OOP capacity was not discussed by the author. Recently, da Porto et al. [16] tested 8 full-scale specimens, with similar geometric characteristics of specimens tested by [39] also to assess the efficiency of strengthening strategies. The authors tested panels made with $\mathrm{HCHB}$, typically characterized by units with a high percentage of voids. One of the conclusions from the study was that the OOP response of panels with previous IP damage was britle, and particular with unstable post-peak behaviour.

\subsection{Cracking strength and secant cracking stiffness}

Some of the authors provided information regarding the moment of formation of the first major visible cracking. The corresponding strength (here designated cracking strength), displacement and secant cracking stiffness were collected. The results obtained by Angel et al. [4], Furtado et al. [32,31] and Ricci et al. [62] were collected and some ratios between the reference specimens and the panels with previous IP damage were performed to evaluate the impact of the IP drift level in the panel OOP response and are summarized in Table 2.

As expected, it was observed that all the specimens reached lower cracking strength for higher levels of previous IP drift which was observed for all the specimens (Fig. 12a). It is proposed the empirical Eq. (10), based on the experimental results to predict the expected ratio between the damaged and undamaged strength with good accuracy $\left(R^{2}=0.71\right)$. The accuracy $(A C C)$ of the prediction proposal approach is plotted in Fig. 12b. A mean ACC of 0.87 , COV equal to $44 \%$ and SD equal to 0.38 were found.

Regarding the secant cracking stiffness $\left(\mathrm{K}_{\text {crack,sec }}\right)$ the same tendency is observed (Fig. 12c, however some differences can be found: i) the specimen IP_OOP_L achieved a secant stiffness $20 \%$ larger than the reference specimen. Result that is clearly out of the other results presented; ii) the result obtained by Furtado et al. [32,31] is slightly higher than the expected a IP drift equal 


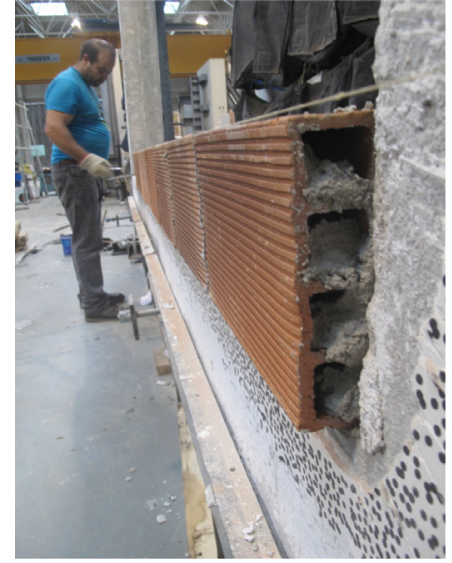

a)

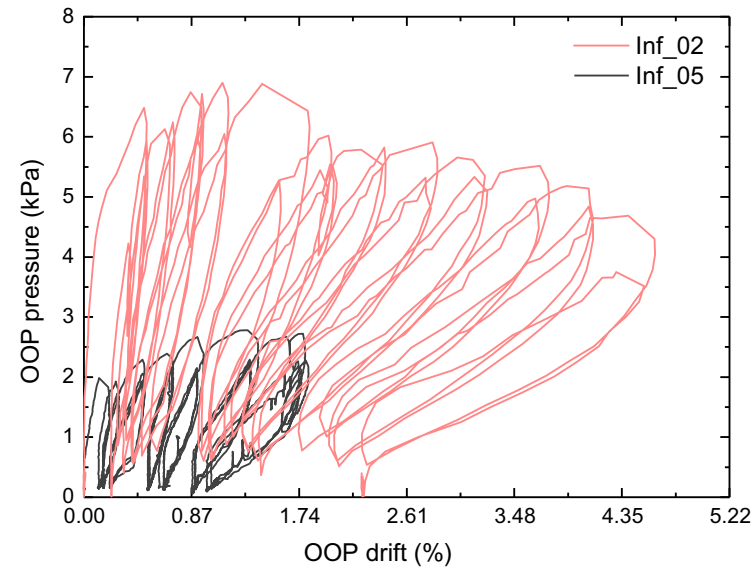

b)

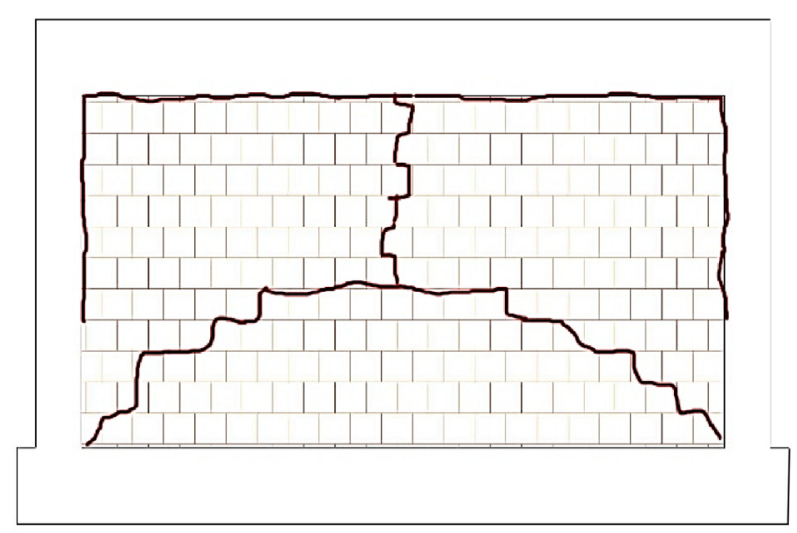

Inf 02

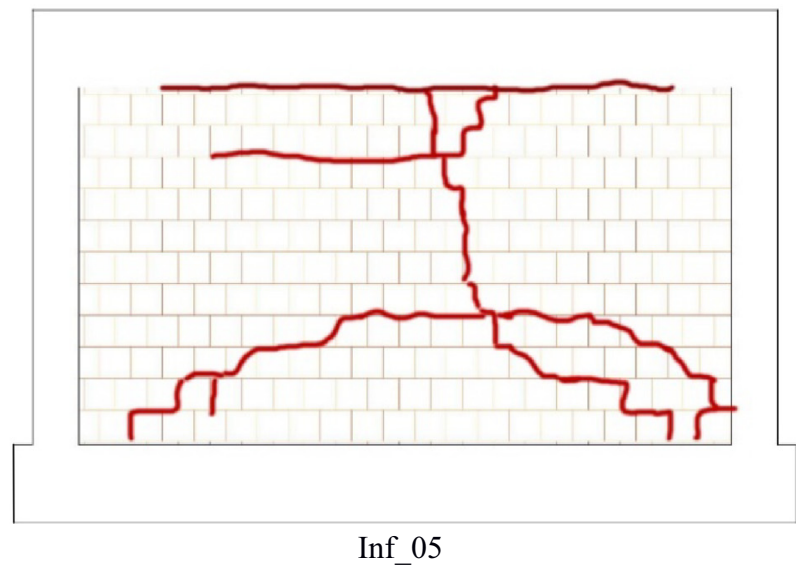

c)

Fig. 11. Support condition effect study carried out by Furtado et al. [32,31]: a) construction procedure; b) Force-displacement curve; and c) cracking pattern.

to $0.5 \%$. The Specimen Inf_03 achieved a ratio of 0.28 , which is higher than the ones obtained by specimen 3 and IP_OOP_M for IP drifts equals to $0.34 \%$ and $0.37 \%$ respectively. Eq. (11) is proposed to predict the expected ratio between the damaged and undamaged secant cracking stiffness for the different previous IP drift levels. Lower ACC was achieved, and it was observed that this proposal overestimate the cracking secant stiffness ratio. ACC was limited (Fig. 12d) by the results of specimens Inf_03, IP_OOP_H, 2b and IP_OOP_M. The ACC of the equation proposed to predict the secant cracking stiffness obtained a mean of 1.28 and $\mathrm{COV}$ equal to $40 \%$.

$\left(\frac{F_{\text {crack,damaged }}}{F_{\text {crack, undamaged }}}\right)=0.1247 \times I P_{\text {prev }}^{-1.06}$

$\left(\frac{K_{\text {crack,damaged }}}{K_{\text {crack, undamaged }}}\right)=0.0297 \times I P_{\text {prev }}^{-1.818}$

\subsection{Maximum strength and secant stiffness}

The specimens' maximum strength of Angel et al. [4], Calvi and Bolognini [13], Furtado et al. [32,31] and Ricci et al. [62] tests were collected in order to perform some ratios between the reference specimens and the panels with previous IP damage (Table 3$)$. The same procedure was performed for the secant stiffness $\left(K_{\mathrm{sec}}\right)$.

The maximum strength and secant stiffness ratios between the results obtained by the undamaged and damaged panels are plotted in function of the corresponding previous IP drift are plotted in
Figs. 13a and 11c. From the results it can be observed a clear tendency of the $F_{\max }$ reduction with the increase of the previous IP drift demand. A power trend line was found to follow all the test results with a good correlation $\left(\mathrm{R}^{2}=0.90\right)$ and is indicated in Fig 13a and is given by Eq. (12). Better results were obtained for the maximum strength ratio prediction with a mean ACC of 0.96 and a COV equal to 25\%. Specimen 6, 2 and Inf_03 contributed significantly for the COV increment (Fig. 13b).

The ratios between the damaged and undamaged specimen's secant stiffness obtained similar results (Fig. 13c), however ACC of the proposed Eq. (13) is limited by the result specimen IP_OOP_L $\left(R^{2}=0.68\right)$. The mean ACC of the secant stiffness prediction Equation is of 1 , however COV and SD increased to $53 \%$ and 0.54 respectively.

$\left(\frac{F_{\text {max,damaged }}}{F_{\text {max } \text {,undamaged }}}\right)=0.1638 \times I P_{\text {prev }}^{-0.946}$

$\left(\frac{F_{\text {max }, \text { damaged }}}{F_{\text {max } \text {,undamaged }}}\right)=0.0308 \times I P_{\text {prev }}^{-1.662}$

\subsection{IP-OOP collapse drift}

No recommendations can be found over the international codes regarding the IP-OOP collapse displacement. It can be only found some considerations specifically for IP or OOP limit drifts directions. FEMA274 [22] indicate that the Immediate Occupancy Performance Level is not necessarily related to initial cracking of a 
Table 2

Effect of previous IP damage: cracking strength and secant cracking stiffness.

\begin{tabular}{|c|c|c|c|c|c|c|}
\hline \multirow[t]{2}{*}{ Author } & \multirow[t]{2}{*}{ Specimen } & \multirow[t]{2}{*}{ Previous IP drift (\%) } & \multicolumn{2}{|c|}{ Cracking Strength $\mathrm{F}_{\text {crack }}(\mathrm{kPa})$} & \multicolumn{2}{|c|}{$\begin{array}{l}\text { Secant Cracking Stiffness } K_{\text {crack,sec }} \\
(\mathrm{kN} / \mathrm{mm})\end{array}$} \\
\hline & & & Test result & Ratio Dam/refer & Test result & Ratio Dam/refer \\
\hline \multirow[t]{3}{*}[4]{} & 1 & 0 & 4.31 & $\mathrm{~N} / \mathrm{A}$ & 5.18 & $\mathrm{~N} / \mathrm{A}$ \\
\hline & 3 & 0.22 & 1.89 & 0.74 & 1.61 & 0.31 \\
\hline & $2 b$ & 0.34 & 3.20 & 0.44 & 1.04 & 0.20 \\
\hline \multirow[t]{2}{*}[32,31]{} & Inf_02 & 0 & 5.17 & $\mathrm{~N} / \mathrm{A}$ & 20.75 & $\mathrm{~N} / \mathrm{A}$ \\
\hline & Inf_03 & 0.5 & 1.86 & 0.36 & 7.83 & 0.28 \\
\hline \multirow[t]{4}{*}{ [62] } & OOP_4E & 0 & 4.51 & $\mathrm{~N} / \mathrm{A}$ & 5.88 & $\mathrm{~N} / \mathrm{A}$ \\
\hline & IP_OOP_L & 0.16 & 2.93 & 0.65 & 7.00 & 1.19 \\
\hline & IP_OOP_M & 0.37 & 1.98 & 0.44 & 0.73 & 0.12 \\
\hline & IP_OOP_H & 0.58 & 0.60 & 0.13 & 0.28 & 0.05 \\
\hline
\end{tabular}

N/A: Not applicable.

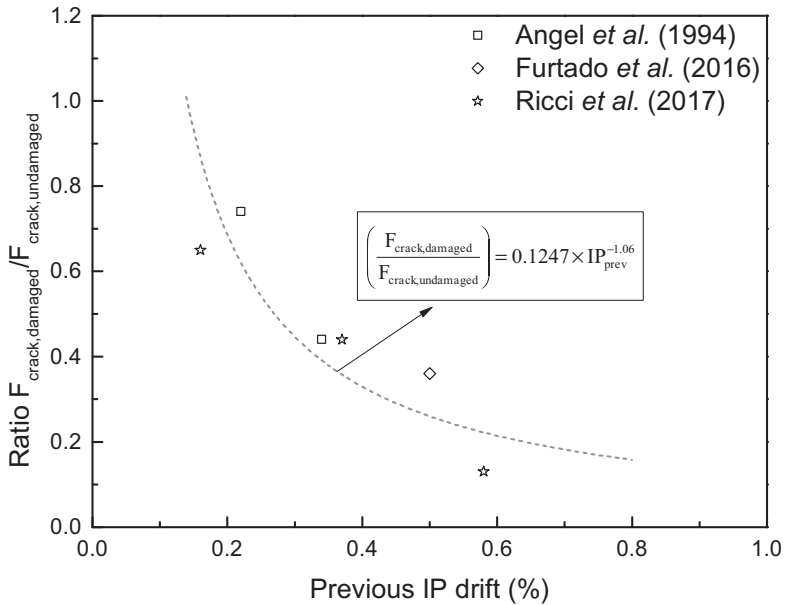

$\left(\mathrm{R}^{2}=0.71\right)$

a)

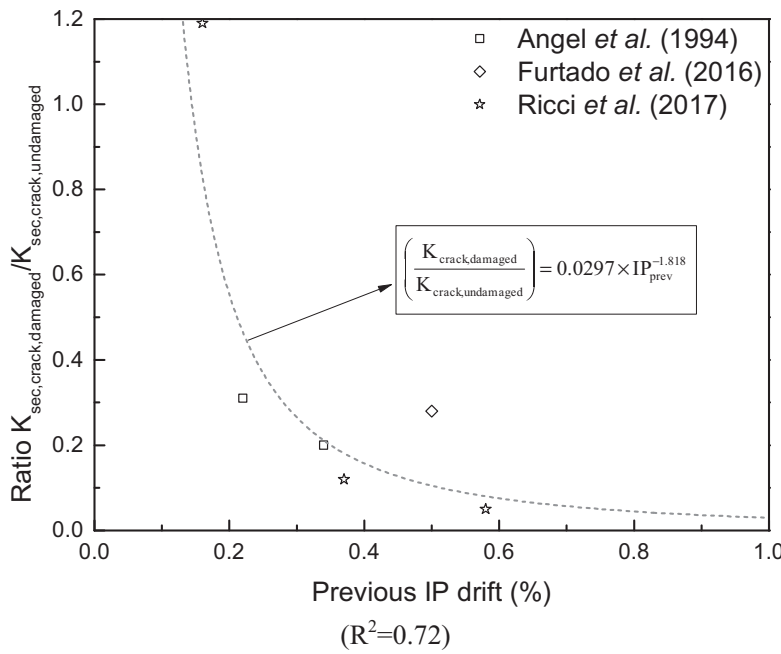

c)

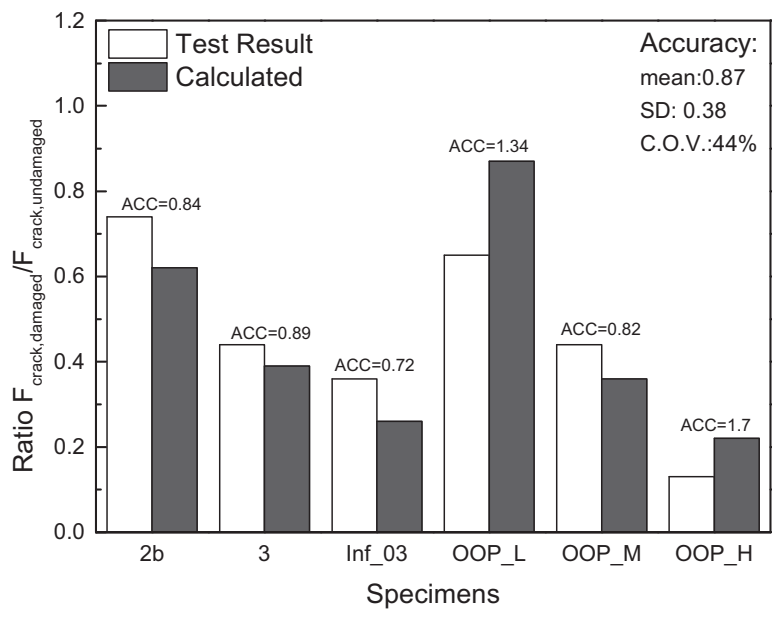

b)

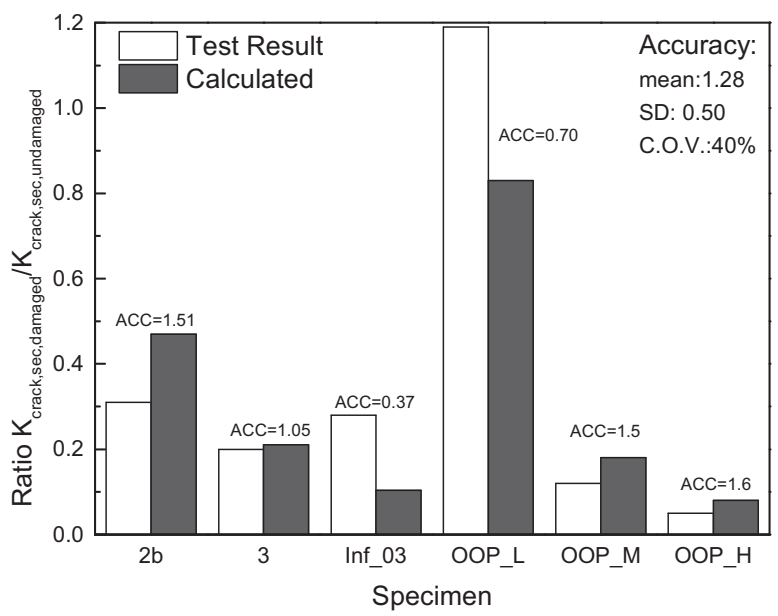

d)

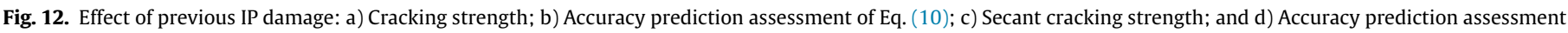
of Eq. (11).

wall. Some cracking can be tolerated for typical occupancy conditions. Life Safety is related to extensive cracking of the infill panel. If arching action can be developed, the lateral story drift ratio of the slenderest panel allowed (slenderness equal to 20 ) will be $2.8 \%$, which is just less than the limit of $3 \%$ given for Life Safety. Thus, all infills that can develop arching mechanisms can meet this required Performance Level, since their strength will be sufficient to resist to the inertial forces.
FEMA356 [23] recommended three limit states: 1) Immediate Occupancy Structural Performance Level: OOP drift $\leq 2 \%$; 2) Life Safety Structural Performance Level: OOP drift $\leq 3 \%$; c) Collapse Prevention Structural Performance Level: OOP drift $\leq 5 \%$. It is also indicated that if the surrounding frame is shown to remain stable following the loss of an infill panel, infill panels shall not be subject to limits for the Collapse Prevention Structural Performance Level. Acceptable deformations of existing and new walls shall be 
Table 3

Effect of previous IP damage: maximum strength and secant stiffness.

\begin{tabular}{|c|c|c|c|c|c|c|}
\hline \multirow[t]{2}{*}{ Author } & \multirow[t]{2}{*}{ Specimen } & \multirow[t]{2}{*}{ Previous IP drift } & \multicolumn{2}{|c|}{ Maximum Strength $\mathrm{F}_{\mathrm{Max}}(\mathrm{kPa})$} & \multicolumn{2}{|c|}{ Secant Stiffness $\mathrm{K}_{\mathrm{sec}}(\mathrm{kN} / \mathrm{mm})$} \\
\hline & & & Test result & Dam/refer & Test result & Dam/refer \\
\hline \multirow[t]{3}{*}[4]{} & 1 & 0 & 8.18 & $\mathrm{~N} / \mathrm{A}$ & 3.33 & $\mathrm{~N} / \mathrm{A}$ \\
\hline & 3 & 0.22 & 5.98 & 0.73 & 1.03 & 0.31 \\
\hline & $2 b$ & 0.34 & 4.02 & 0.49 & 0.89 & 0.27 \\
\hline \multirow[t]{3}{*}{ [13] } & 10 & 0 & 2.92 & $\mathrm{~N} / \mathrm{A}$ & 6.74 & $\mathrm{~N} / \mathrm{A}$ \\
\hline & 6 & 0.4 & 0.77 & 0.26 & 0.49 & 0.07 \\
\hline & 2 & 1.2 & 0.51 & 0.17 & $\mathrm{~N} / \mathrm{R}$ & $\mathrm{N} / \mathrm{A}$ \\
\hline \multirow[t]{2}{*}[32,31]{} & Inf_02 & 0 & 7.23 & $\mathrm{~N} / \mathrm{A}$ & 5.41 & $\mathrm{~N} / \mathrm{A}$ \\
\hline & Inf_03 & 0.5 & 1.85 & 0.26 & 1.18 & 0.22 \\
\hline \multirow[t]{4}{*}[62]{} & OOP_4E & 0 & 5.12 & $\mathrm{~N} / \mathrm{A}$ & 4.07 & $\mathrm{~N} / \mathrm{A}$ \\
\hline & IP_OOP_L & 0.16 & 5.44 & 1.06 & 3.44 & 0.85 \\
\hline & IP_OOP_M & 0.37 & 2.44 & 0.48 & 0.33 & 0.10 \\
\hline & IP_OOP_H & 0.58 & 1.37 & 0.27 & 0.23 & 0.07 \\
\hline
\end{tabular}

N/A: Not applicable.

N/R: Result not provided by the author.

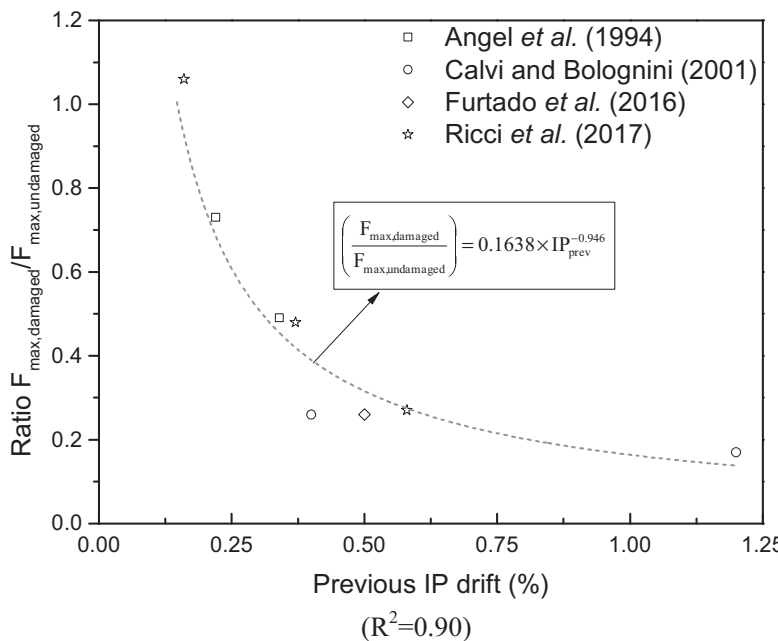

a)

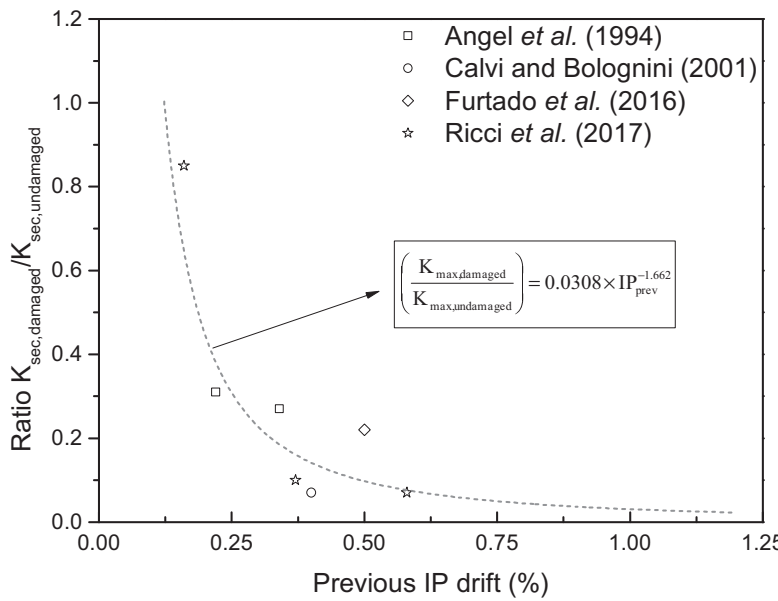

$\left(\mathrm{R}^{2}=0.68\right)$

c)

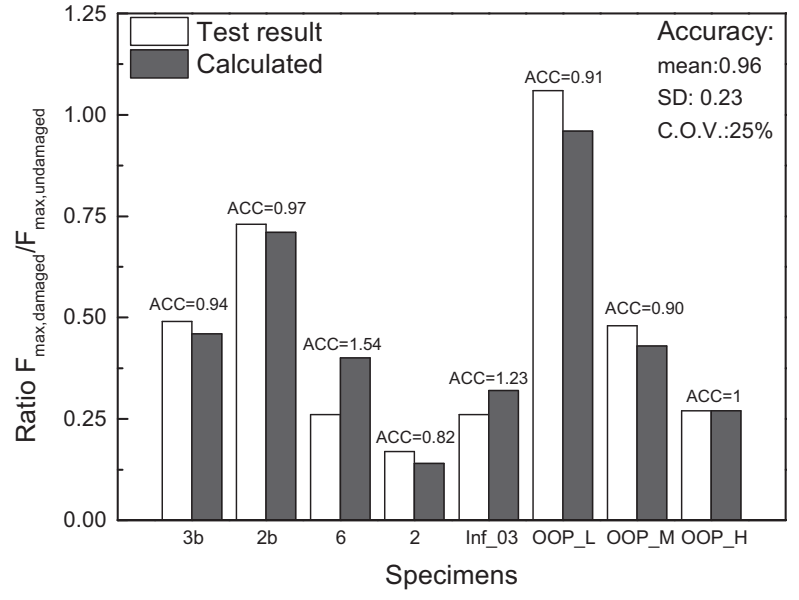

b)

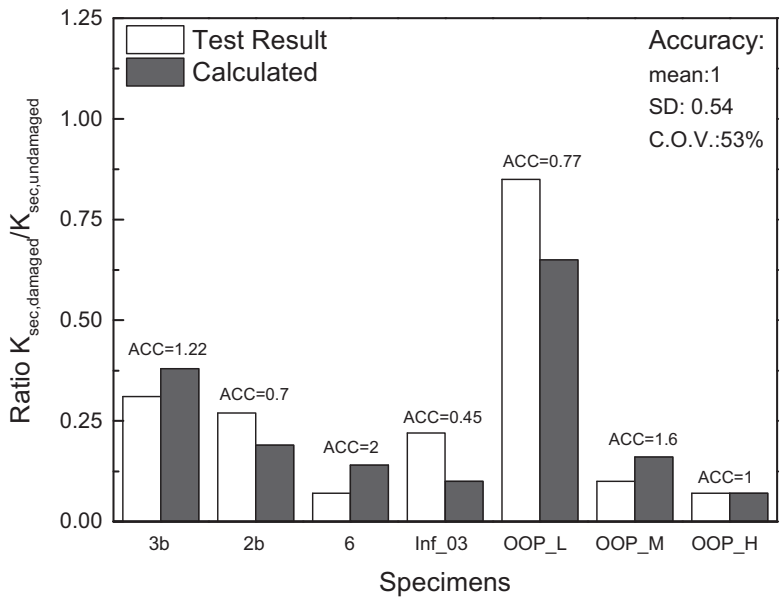

d)

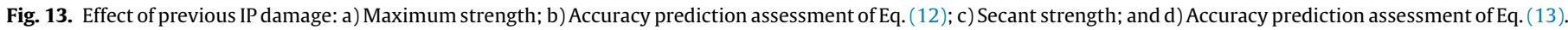

assumed to be the same. Similar recommendations are provided by ASCE41-13 [5].

Over the literature some recommendations are provided by authors based on experimental evidences. For example Angel et al. [4] propose maximum OOP displacement equal to 0.8 times the panel thickness which corresponds to the activation point of the panel OOP instability. Kadysiewski and Mosalam [43] and Furtado et al. [32,31] suggested that the OOP displacement occurs for 5 times the maximum strength OOP displacement. Based on the test results analyzed within this section it cannot be achieved solid 
conclusions regarding this point. Even for the as-built panels' results obtained by the authors were characterized by some variability due to the several variables involved and discussed in section 4.

\section{Retrofit strategies: From the definition to the experimental assessment}

\subsection{Background}

Retrofit and improvement of infill masonry walls behaviour under earthquake loads is a complex subject, as it cannot be disconnected from its effect on the overall building response. It is paramount to take this coupled behaviour into consideration. In this context, two main approaches can be found in the Literature: i) engineered infill masonry walls; and ii) retrofitting of the panel. In fact, several efforts were made during the last years by innumerous authors in order to develop efficient retrofit strategies to improve the infill masonry walls OOP capacity. Throughout the present section the different retrofit strategies adopted by the different authors to improve the infill panels OOP capacity will be presented as well as the main findings.

\subsection{Engineered infill masonry walls}

Mohammadi et al. [53] proposed the concept of engineered infilled frames through the introduction of sliding layers in the infill panels. The main concept of this strategy is that some parts of the columns or horizontal layers in infills (called fuses) yield or slid before the infill cracking. It is worth noting that the top gap, between the infill and beam was filled with a high-strength concrete layer. The authors concluded that supplying the infills with sliding fuses had the following advantages: (1) increased the deformation capacity and consequently the ductility of the infilled frame, to meet drift demands in earthquakes, normally being approximately $2.5 \%$; (2) avoided necking in cyclic load-displacement behaviour for non-fused specimens; (3) prevented damage or cracking in the wall during earthquakes; and (4) the sliding fuse was installed without being reliant on any significant changing in the configuration of the frame of infill. Despite the advantages two main defects were pointed, namely: (1) increment of the vulnerability of shear failure in some areas in columns and (2) creation of a potential surface for out-of-plane movement of the wall in the fuse area. The defects were avoided by the authors in the second group of specimens by including a $30 \mathrm{~mm}$ chamfering the infills corners near the fuse and by improving the fuse configuration to restrict transversal sliding. The fuse, referred here as frictional sliding fuse, was introduced at the panel mid-height of the second group of specimens. To study the transversal behaviour of the engineered infilled frame, a specimen was subjected to an OOP loading applied in eight points. The specimen was driven back to its normal position, zero drift, after being firstly subjected to an IP loading.

Preti et al. $[59,61,60]$ developed a similar design solution with sliding joints to reduce the infill-frame interaction and ensure OOP stability. The authors validated the potential of the horizontal partition joints (embedded in few masonry mortar beds and acting as sliding joints) to ensure a ductile mechanism for the infill under IP loading, which during the tests prevented the development of the typical diagonal strut mechanism. The OOP failure was observed to occur with a ductile mechanism, at a load equivalent to a horizontal acceleration 4 times the acceleration of gravity. Such strength appeared to be not affected by several cycles applied IP up to $2.5 \%$ drift and this was consistent with the marginal damage suffered by the infill for IP load, even at large deformation.
Other types of engineered IM solutions were proposed by using disconnection using gap [57] and partial disconnection using energy dissipation devices [3].

\subsection{Retrofitting of the IM panel}

The integration of the infill panels on the substructure and respective behaviour improvement can be achieved using different strengthening techniques such for example: fiber reinforced polymers (FRP) [2,20], engineered cementitious composites [47] and reinforced mortars [13]. The knowledge and techniques to improve the way infill masonry walls response to earthquakes were already been studied and tested, however in parallel to these advances in the last years and due to the concerns with the thermal comfort new bricks and new techniques have also been developed for the building's façade walls with the main goal of reduce the cooling and heating losses. As result of the innovation new types of masonry units and construction technologies were developed, being pushed by the market competition. The masonry industry improved the thermal properties of masonry units and developed new, faster and cheaper technologies of construction [70]. The use of External Thermal Insulation Composite Systems (ETICS) is now common in the external walls with the energy saving propose. Distinct types of ties, generally from steel or plastic and having different shapes and geometry, much dependent on the walls system are usually adopted [14].

Different strategies to retrofit the panel were adopted and tested by different authors to improve the OOP capacity of infill masonry walls subjected to OOP loadings. Dawe and Seah [17] tested the benefits of use bed joints reinforcement. Specimens WE1 and WE7 incorporated bed joints reinforcement at alternated courses and it was verified a considerably increase of the panels deformation capacity. Higher cracking strength was also pointed by the authors. Angel et al. [4] repaired three specimens that were previously subjected to OOP monotonic tests. The repair method consists on the introduction a half-inch thick ferrocement coating to one or both faces of the panel. A single sheet wire mesh was placed on each face. The wire mesh was embedded in the coating. Multiple wire sheets were lapped spliced to cover the entire infill surface area. The wire mesh was anchored to the damaged infill by steel bolts. A flexible PVC sleeve was placed over the bolts to provide relaxation to the system, and prevent premature cracking of the coating. The authors concluded that the maximum OOP strength capacity increased about 5 times. Due to this, the authors concluded that the repair strategy efficiency was not affected by the level of the panel previous damage. The authors also observed that the repair methods were very efficient due to the panels' lower slenderness ratio and due to the fact that the compressive strength of the repairing material was higher than the damaged infill panel material.

Calvi and Bolognini [13] tested two different retrofit strategies in the experimental campaign of IP-OOP tests: bed joints reinforcement and external reinforcement combined with bed joints reinforcement. The external reinforcement was composed by a mortar layer reinforced. No detailed information was provided regarding the design of the retrofit solution. From the results the authors concluded that presence of little reinforcement improves significantly the panel response in terms of damage limit states. Pereira et al. [58] carried out a series of combined IP-OOP tests, in scaled specimens, with different bed joints reinforcement (JAR) and reinforced plaster (RAR). Different disposition of the reinforcement was considered, namely vertical and horizontal bed joints reinforcement. Both retrofitted specimens reached approximately 4 times higher stiffness than the reference wall. The RAR showed a typical slab failure mode, since the plaster hold the masonry and prevented the wall failure and expulsion. The authors 
also concluded that both tend to increase the stiffness of the structures.

Lunn and Rizkalla [50] developed an extensive experimental campaign composed by 14 full-scale infilled RC frames specimens, which included four un-strengthened specimens and 10 strengthened specimens. The strengthened specimens were reinforced with externally bonded glass fiber-reinforced polymer (GFRP) sheets applied to the exterior tension face of the outer leaf. Different coverage ratio was adopted with unidirectional (vertical and horizontal) directions. Three different anchorage systems were used. The authors concluded that the externally bonded GFRP strengthening system was effective if proper anchorage of the FRP laminate is guaranteed. Overlapping the FRP reinforcement onto the RC frame revealed to be very effective for double wythe specimens, but less so for single wythe specimens.

Guidi et al. [39] carried out combined IP-OOP tests with the aim of characterize the OOP behaviour of infill masonry walls made with different types of masonry units, with and without reinforcement. Two specimens were unreinforced and other two were made of reinforced masonry, having both horizontal and vertical bed joints reinforcement. The remaining two specimens were built with thin $(120 \mathrm{~mm})$ clay units with plaster layer, one of them was strengthened by means of a special quadriaxial net made with hybrid glass fibres, that was casted in an extra fiber-reinforced plaster layer. From the test results, it was observed that the thick masonry systems tested (both reinforced and unreinforced) presented higher OOP strength, due to the development of an arch mechanism, even for higher values of previous IP drift. The thinner specimens, even when strengthened, developed a bending out-ofplane failure that somehow limited the panel strength. Finally, the authors pointed that previous IP damages were affected by the presence of strengthening or reinforcement. Similarly, da Porto et al. [16] evaluate the effectiveness of plasters and textile reinforced mortars for strengthening clay infill masonry walls made with HCHB subjected to combined IP-OOP tests. Different solutions were tested, namely: i) special lime-based plaster with geopolymer binder; ii) bidirectional composite meshes with inorganic matrices (textile reinforced mortars TRM); iii) TRM improved by anchorage of the mesh to the RC frame. From the results, the authors pointed that the OOP behaviour of 'light' clay damaged panels after IP test clearly improved with plasters made of natural hydraulic lime, with or without geopolymer binder, reaching around 2.7 times higher OOP strength. The anchorages embedded in the textile reinforced mortars fixed to the upper beam did not change significantly the infill masonry wall OOP capacity. It was also observed a reduction of the displacement at the maximum strength and allowed a highly controlled failure mode to develop after reached the maximum strength.

Finally, Silva [65] carried out an experimental campaign composed by 8 combined and not IP-OOP tests to assess the seismic behaviour two innovative retrofit solutions, that consisted on the use of different masonry units combined with the introduction of reinforcement to improve their capacity. One of the details of the solutions proposed by the authors is the intention of improve also the thermal insulation characteristics of the panels. Two systems were proposed and tested: uniko and termico systems. The uniko system is characterized by the use a single-leaf clay masonry enclosure to be taken for low to medium height residential/commercial RC buildings with framed structure and for zones of medium intensity seismic hazard. The Uniko System is composed by VHCB masonry units. This unit use interlocking along the length. To take advantage of the energy dissipation capacity at the interlocking joints, due to sliding between the masonry units, it was placed the masonry units aligned with the length in the vertical direction and thus, with continuous vertical joints. Additionally, it was introduced steel rebars in the face of masonry units, which were connected at top and bottom RC beams/slabs. Therefore, the masonry infill has dry vertical joints and mortared bed joints. The Termico system is characterized by use the concept of maintain the infill rigidly attached to the frame, using internal reinforcement and connectors between the infill and frame. From the results it was achieved good improvement of the panels' capacity such in terms of strength and deformation capacity. Globally, the uniko system results were: i) $40-50 \%$ higher OOP strength for undamaged and damaged panels; ii) $20-40 \%$ increment of the displacement at the OOP maximum strength. Regarding the Termico system it was obtained 19\% maximum strength increment for the undamaged panel and 33\% for a panel subjected to previous $0.54 \%$ drift. However, the specimen subjected to $1.05 \%$ of IP drift achieved a reduction of $20 \%$ of the maximum strength. No technical details were provided by the author to justify this result.

There are some studies developed regarding the use of thermal bricks, especially in new masonry constructions, but there is a lack of experimental studies to characterize the infill panels OOP behaviour with this masonry units.

\section{Conclusions}

The main objective of this paper was to present a general review of experimental tests carried out to characterize the infill masonry wall OOP behaviour. A brief summary of the main variables and aspects that distinguish each test campaign was presented. For this a systematic review methodology was adopted to filtering only the works in which the scope of the present research is in agreement. The complexity inherent to the OOP behaviour of this elements is reflected by the amount of variables consider throughout the tests analyzed, such as the panel geometries, masonry units, openings, border constrains, gravity load, previous IP damage and retrofit strategies. This review provides new findings that support the characterization of the OOP seismic behaviour of infill masonry walls. The main findings achieved from the global overview of the different test campaigns are:

- Airbag is the most common approach adopted to apply the OOP loading;

- $12 \%$ of the tests from the literature are IP-OOP;

- Only $17 \%$ of the tests combined the gravity and the OOP load, some of the authors pointed the complexity of the experimental setup as limitation;

- Large variation of the were found regarding the specimen's geometric dimensions, however it was observed that panels slenderness very between 10 and 56 and aspect ratio between 0.4 and 1.6.

The main findings achieved from as-built specimens testing campaigns are:

- The maximum OOP strength capacity depends greatly of the panel slenderness;

- The ultimate OOP strength increase with the increasing of the panel thickness, but decrease with the length and height;

- Cracking patterns depends of the panel aspect ratio;

- The infill masonry walls follows a linear elastic behaviour up to the formation of the first crack. After that, the behaviour observed is nonlinear. This nonlinearity is related to the presence of new cracks and the propagation of existing ones up to the formation of the final cracking pattern;

- Workmanship could significantly affect the panel OOP behaviour by disturbing their boundary conditions;

- The maximum OOP deformation is observed in panels made with solid bricks; 
- The masonry compression strength revealed to be more important to the formation of the arching mechanism than the tensile strength;

- The masonry properties play an important role in the OOP response of the panel, and it is observed that with an increment of $0.5 \mathrm{MPa}$ of the flexural strength parallel to the horizontal bed joints the panel increase the OOP maximum strength 5 times;

\section{The main findings achieved from IP-OOP testing campaigns are:}

- The IP-OOP combined interaction is still an open issue due to the reduced amount of data available in the literature;

- Empirical relationships were proposed to obtain the maximum strength, secant stiffness, cracking stiffness and secant cracking stiffness for specimens subjected to IP-OOP tests, based in the data with good accuracy;

- It was observed that previous damage due to IP previous loading demands reduce the OOP initial stiffness, strength and potentiate fragile ruptures which can lead to fragile OOP expulsions. This is due to the loss of the boarder constrains that were modified, since the detachment of the panel from the surrounding frame occurred and a rigid body behaviour occurs when subjected to OOP loadings

From the total collected experimental data, only 29 specimens can be included in a possible OOP-IM database with complete inputs and outputs (geometric dimensions, frame detailing, loading condition, material and mechanical properties and force-displacement results).

Finally, it was discussed different retrofit strategies adopted by over the literature to improve the panel OOP performance. The use of bed joints reinforcement is pointed as a solution with good efficiency, since provide deformation capacity to the panel. Other solutions such as reinforced plasters are also pointed as solutions with good results, and the connection between the panels and the frame are one of the detail aspects that limited the performance of these solution. In order to complement the present study and the global findings, the evaluation of the differences between the full-scale and scaled tests should be performed in the future.

\section{Acknowledgments}

The first, third and fourth author would like to acknowledge the support financially support by: Project POCI-01-0145-FEDER007457 - CONSTRUCT - Institute of R\&D In Structures and Construction funded by FEDER funds through COMPETE2020 Programa Operacional Competitividadee Internacionalização (POCI) - and by national funds through FCT - Fundaca o para a Ciência e a Tecnologia, Portugal; namely through there search project P0CI-01-0145-FEDER-016898 - ASPASSI - Safety Evaluation and Retrofitting of Infill masonry enclosure Walls for Seismic demands. In addition, the second author would like to acknowledge the financial support to the research Unit RISCO (FCT/UID/ ECI/04450/2013) also funded by FEDER - Portugal funds through COMPETE2020 - Programa Operacional Competitividadee Interna cionalização (POCI) - and by national funds through FCT - Fundaca o para a Ciência e a Tecnologia of Portugal. The authors also acknowledge the constructive comments and suggestions given by the anonymous reviewers which improved the quality of the manuscript.

\section{References}

[1] F. Akhoundi, G. Vasconcelos, P. Lourenço, B. Silva. Out-of-plane response of masonry infilled RC frames: effect of workamnship and opening. Brick and Block Masonry Conference (IB2MAC) Padua, Italy, 2016
[2] E. Akin, G. Ozcebe, U. Ersoy, Strengthening of brick infilled reinforced concrete (RC) frames with carbon fiber reinforced polymers (CFRP) sheets, in: A. Ilki, F Karadogan, S. Pala, E. Yuksel (Eds.), Seismic Risk Assessment and Retrofitting: With Special Emphasis on Existing Low Rise Structures, Springer, Netherlands, Dordrecht, 2009, pp. 367-386.

[3] M. Aliaari, A.M. Memari, Experimental evaluation of a sacrificial seismic fuse device for masonry infill walls, J. Architect. Eng. 13 (2) (2007) 111-125.

[4] R. Angel, D. Abrams, D. Shapiro, J. Uzarski, M. Webster, Behavior of reinforced concrete frames, with masonry infills, Civil Engineering Studies, Reserach Series No. 589, UILU-ENG, Department of Civil Engineering, University of Ilinois, USA, pages, 94-2005, 1994.

[5] ASCE41-13, Seismic Evaluation and Retrofit of Existing Buildings, 2014.

[6] P. Asteris, S. Antoniou, D. Sophianopoulos, C. Chrysostomou, Mathematical Macromodeling of Infilled Frames: State of the Art, J. Struct. Eng. 137 (12) (2011) 1508-1517.

[7] P. Asteris, D. Cotsovos, C. Chrysostomou, A. Mohebkhah, G. Al-Chaar, Mathematical micromodelling of infilled frames: state of the art, Eng. Struct. 56 (2013) 1905-1921.

[8] P.G. Asteris, L. Cavaleri, F. Di Trapani, V. Sarhosis, A macro-modelling approach for the analysis of infilled frame structures considering the effects of openings and vertical loads (In Press), Struct. Infrastruct. Eng. (2015).

[9] N. Augenti, F. Parisi, E. Acconcia, MADA: online experimental database for mechanical modelling of existing masonry assemblages, Proc., Fifteenth World Conference on Earthquake Engineering, Lisbon, Portugal

[10] A.R. Barbosa, L.A. Fahnestock, D.R. Fick, D. Gautam, R. Soti, R. Wood, B. Moaveni, A. Stavridis, M.J. Olsen, H. Rodrigues, Performance of medium-tohigh rise reinforced concrete frame buildings with masonry infill in the 2015 Gorkha, Nepal, Earthquake, Earthq. Spectra 33 (S1) (2017) S197-S218.

[11] M. Beconcini, Sulla resistenza a forze orizzontali di pareti in elementi forati in laterizio, Construire in laterizio 55 (1997) 60-69.

[12] I. Cadório, M. Lousada, P. Martins, D. Figueired, Generalization and maintenance of treatment gains in primary progressive aphasia (PPA): a systematic review, Int. J. Lang. Commun. Disord. 52 (5) (2017) 543-560.

[13] G. Calvi, D. Bolognini, Seismic response of reinforced concrete frames infilled with weakly reinforced masonry panels, J. Earthq. Eng. 5 (2) (2001) 153-185.

[14] A. Collina, G. Lignola, The external thermal insulation composite system (ETICS) more than comfort and energy saving, 3rd Portuguese Congress on Construction Mortars (APFAC), 2010.

[15] G. Corte, L. Fiorinho, F. Mazzolani, Lateral-loading tests on a real RC building including masonry infill panels with and without FRP strengthening, J. Mater. Civ. Eng. 20 (6) (2008) 419-431.

[16] F. da Porto, G. Guidi, N. Verlato, C. Modena, Effectiveness of plasters and textile reinforced mortars for strengthening clay masonry infill walls subjected to combined in-plane/out-of-plane actions/Wirksamkeit von Putz und textilbewehrtem Mörtel bei der Verstärkung von Ausfachungswänden aus Ziegelmauerwerk, die kombinierter Scheiben- und Plattenbeanspruchung ausgesetzt sind, Mauerwerk 19 (5) (2015) 334-354.

[17] J. Dawe, C. Seah, Out-of-plane resistance of concrete masonry infilled panels, Can. J. Civ. Eng. 16 (6) (1989) 854-864.

[18] J.C. de la Llera, F. Rivera, J. Mitrani-Reiser, R. Jünemann, C. Fortuño, M. Ríos, M. Hube, H. Santa María, R. Cienfuegos, Data collection after the 2010 Maule earthquake in Chile, Bull. Earthq. Eng. 15 (2) (2017) 555-588.

[19] F. De Luca, G. Verderame, F. Gómez-Martinez, A. Pérez-García, The structural role played by masonry infills on RC buildings performances after the 2011 Lorca, Spain, earthquake, Bull. Earthq. Eng. 12 (2014) 1999-2006.

[20] M.A. ElGawady, P. Lestuzzi, M. Badoux, In-plane seismic response of URM walls upgraded with FRP, J. Compos. Construct. 9 (6) (2005) 524-535.

[21] M. Fardis, S. Bousias, G. Franchioni, T. Panagiotakos, Seismic response and design of RC structures with plan-eccentric masonry infills, Earthq. Eng. Struct. Dynam. 28 (1999) 173-191.

[22] FEMA274, NEHRP commentary on the guidelines for the seismic rehabilitation of buildings. FEMA-274, Applied Technology Council, Washington, USA, Federal Emergency Management AgencyWashington, (DC), 1997.

[23] FEMA356, Pre-standard and commentary for the seismic rehabilitation of buildings, FEMAgency, Washington, DC, 2000.

[24] T.M. Ferreira, A.A. Costa, A. Arêde, A. Gomes, A. Costa, Experimental characterization of the out-of-plane performance of regular stone masonry walls, including test setups and axial load influence, Bull. Earthq. Eng. 13 (9) (2015) 2667-2692.

[25] T.M. Ferreira, A.A. Costa, A. Arêde, H. Varum, A. Costa, In situ Out-of-plane cyclic testing of original and strengthened traditional stone masonry walls using airbags, J. Earthq. Eng. 20 (5) (2016) 749-772.

[26] G. Fiorentino, A. Forte, E. Pagano, F. Sabetta, C. Baggio, D. Lavorato, C. Nuti, S. Santini, Damage patterns in the town of Amatrice after August 24th 2016 Central Italy earthquakes, Bull. Earthq., Eng, 2017.

[27] R. Flanagan, R. Bennett, Bidirectional behaviour of structural clay tile infilled frames, J. Struct. Eng. 125 (3) (1999) 236-244.

[28] V. Frederiksen, Membrane effect in laterally loaded masonary walls. A second order phenomenon, 6th Canadian Masonry Symposium, University of Saskatchewan, Canada, 1992

[29] A. Furtado, C. Costa, A. Arêde, H. Rodrigues, Geometric characterisation of Portuguese RC buildings with masonry infill walls, Eur. J. Environ. Civ. Eng. (2016) 1-16.

[30] A. Furtado, H. Rodrigues, A. Arêde, Modelling of masonry infill walls participation in the seismic behaviour of RC buildings using OpenSees, Int. J. Adv. Struct. Eng. (IJASE) 7 (2) (2015) 117-127. 
[31] A. Furtado, H. Rodrigues, A. Arêde, H. Varum, Experimental evaluation of outof-plane capacity of masonry infill walls, Eng. Struct. 111 (2016) 48-63.

[32] A. Furtado, H. Rodrigues, A. Arêde, H. Varum, Simplified macro-model for infill masonry walls considering the out-of-plane behaviour, Earthq. Eng. Struct. Dynam. 45 (4) (2016) 507-524.

[33] A. Furtado, H. Rodrigues, A. Arêde, H. Varum, Modal identification of infill masonry walls with different characteristics, Eng. Struct. 145 (2017) 118-134.

[34] A. Furtado, H. Rodrigues, H. Varum, A. Costa, Evaluation of different strengthening techniques' efficiency for a soft storey building, Eur. J. Environ. Civ. Eng. (2015) 1-18.

[35] D. Gautam, H. Rodrigues, K.K. Bhetwal, P. Neupane, Y. Sanada, Common structural and construction deficiencies of Nepalese buildings, Innov. Infrastruct. Solut. 1 (1) (2016) 1.

[36] M. Griffith, J. Vaculik, Out-of-plane flexural strength of unreinforced clay brick masonry walls, TMS J. 25 (1) (2007) 53-68.

[37] M. Griffith, J. Vaculik, N. Lam, J. Wilson, E. Lumantarna, Cyclic testing of unreinforced masonry walls in two-way bending, Earthq. Eng. Struct. Dynam. 36 (2007) 801-821.

[38] M.C. Griffith, J. Vaculik, N.T.K. Lam, J. Wilson, E. Lumantarna, Cyclic testing of unreinforced masonry walls in two-way bending, Earthq. Eng. Struct. Dynam. 36 (2007) 21.

[39] G. Guidi, F. da Porto, M. Benetta, N. Verlato, C. Modena, Comportamento Sperimentale nel Piano e Fuori Piano di Tamponamenti in Muratura Armata e Rinforzata, XV Convegno Nazionale ANIDIS, L'INGEGNERIA SISMICA IN ITALIA Padova, Italy, 2013.

[40] S. Hak, P. Morandi, G. Magenes, Out-of-plane experimental response of strong masonry infills, 2nd European Conference on Earthquake Engineering and Seismology Turkey, 2014.

[41] L. Hermanns, A. Fraile, E. Alarcón, R. Álvarez, Performance of buildings with masonry infill walls during the 2011 Lorca earthquake, Bull. Earthq. Eng. 12 (2014) 1977-1997.

[42] J. Higgins, S. Green, Cochrane Handbook for Systematic Reviews of Interventions, John Wiley \& Sons, 2011.

[43] S. Kadysiewski, K.M. Mosalam, Modeling of Unreinforced Masonry Infill Walls Considering In-plane and Out-of-Plane Interaction, Pacific Earthquake Engineering Research Center, PEER 2008/102, 2009.

[44] T. Kalman Šipoš, V. Sigmund, M. Hadzima-Nyarko, Earthquake performance of infilled frames using neural networks and experimental database, Eng. Struct. 51 (2013) 113-127.

[45] R. Klingner N. Rubiano T. Bashandy S. Sweeney, Evaluation and analytical verification of shaking table data from infilled frames, 11 th World Conference on Earthquake Engineering Acapulco, Mexico, 1996.

[46] S. Komaraneni, D. Rai, M. Eeri, V. Singhal, Seismic behavior of framed masonry panels with prior damage when subjected to out-of-plane loading, Earthq. Spect. 27 (4) (2011) 1077-1103.

[47] M.A. Kyriakides, S.L. Billington, Cyclic response of nonductile reinforced concrete frames with unreinforced masonry infills retrofitted with engineered cementitious composites, J. Struct. Eng. 140 (2) (2014) 04013046.

[48] T. Liauw, K. Kwan, Experimental study of shear wall and infilled frame on shake-table, 10th World Conference on Earthquake EngineeringMadrid, Spain, 1992.

[49] M. Liu, Y. Cheng, X. Liu, Shaking table test on out-of-plane stability of infill masonry wall, Trans. Tianjin Univ. 17 (2) (2011) 125.

[50] D.S. Lunn, S.H. Rizkalla, Strengthening of infill masonry walls with FRP materials, J. Compos. Construct. 15 (2) (2011) 206-214.

[51] A. Masi, L. Chiauzzi, G. Santarsiero, V. Manfredi, S. Biondi, E. Spacone, C. Del Gaudio, P. Ricci, G. Manfredi, G.M. Verderame, Seismic response of RC buildings during the Mw 6.0 August 24, 2016 Central Italy earthquake: the Amatrice case study, Bull. Earthq. Eng. (2017).

[52] H. Moghaddam, P. Dowling, N. Ambraseys, Shaking table study of brick masonry infilled frames subjected to seismic actions, 9th World Conference on Earthquake Engineering Tokyo, Japan, 1988.

[53] M. Mohammadi, V. Akrami, R. Mohammadi-Ghazi, Methods to improve infilled frame ductility, J. Struct. Eng. 137 (6) (2011) 646-653.

[54] J. Moreno-Herrera, J. Varela-Rivera, L. Fernandez-Baqueiro, Out-of-plane design procedure for confined masonry walls, J. Struct. Eng. 142 (2) (2016) 04015126.

[55] A.S. Mosallam, Out-of-plane flexural behavior of unreinforced red brick walls strengthened with FRP composites, Composites 38 (2007) 16.
[56] M. Mosoarca, C. Petrus, V. Stoian, A. Anastasiadis, Behaviour of masonry infills subjected to out of plane plane seismic actions Part 2: Experiemntal testing, Brick and Block Masonry Conference, Padua, Italy, 2016.

[57] T. Okazaki, M. Nakashima, K. Suita, T. Matusmiya, Interaction between cladding and structural frame observed in a full-scale steel building test, Earthq. Eng. Struct. Dynam. 36 (1) (2007) 35-53.

[58] P. Pereira, M. Pereira, J. Ferreira, P. Lourenço, Behavior of masonry infill panels in RC frames subjected to in plane and out of plane loads, 7th Conference on on Analytical Models and New Concepts in Concrete and Masonry Structure Cracow, Poland, 2012.

[59] M. Preti, N. Bettini, G. Plizzari, Infill Walls with sliding joints to limit infillframe seismic interaction: large-scale experimental test, J. Earthq. Eng. 16 (1) (2012) 125-141.

[60] M. Preti, L. Migliorati, E. Giuriani, Experimental testing of engineered masonry infill walls for post-earthquake structural damage control, Bull. Earthq. Eng. 13 (7) (2015) 2029-2049.

[61] M. Preti, L. Migliorati, E. Giuriani, Experimental testing of engineered masonry infill walls for post-earthquake structural damage control, Bull. Earthq. Eng. 13 (2015) 2029-2049.

[62] P. Ricci, M. Domineco, G. Verderame, Empirical-based out-of-plane URM infill wall model accounting for the interaction with in-plane demand, Earthq. Eng. Struct. Dynam. (2017).

[63] H. Rodrigues, H. Varum, A. Costa, A non-linear masonry infill macro-model to represent the global behaviour of buildings under cyclic loading, Int. J. Mech. Mater. Des. 4 (2) (2008) 123-135.

[64] X. Romão, A.A. Costa, E. Paupério, H. Rodrigues, R. Vicente, H. Varum, A. Costa, Field observations and interpretation of the structural performance of constructions after the 11 May 2011 Lorca earthquake, Eng. Fail. Anal. 34 (2013) 670-692.

[65] L. Silva, Experimental and numerical study of new systems for earthquake resistant masonry enclosures in reinforced concrete buildings, Thesis Project, University of Minho, Guimarães, Portugal, 2017.

[66] L. Silva, G. Vasconcelos, P. Lourenço, F. Akhoundi, Experimental evaluation of a constructive system for earthquake resisting masonry infill walls, Brick and Block Masonry Conference (IB2MAC) Padua, Italy, 2016.

[67] V. Singhal, D.C. Rai, Role of toothing on in-plane and out-of-plane behavior of confined masonry walls, J. Struct. Eng. 140 (9) (2014) 04014053.

[68] E. Smyrou, C. Blandon, S. Antoniou, R. Pinho, F. Crisafulli, Implementation and verification of a msonry panel model for nonlinear dynamic analysis of infilled RC frames, Bull. Earthq. Eng. 9 (2011) 1519-1534.

[69] A. Stavridis, I. Koutromanos, P. Shing, Shake-table tests of a three-story reinforced concrete frame with maosnry walls, Earthq. Eng. Struct. Dynam. 41 (2012) 1089-1108.

[70] M. Tomaževič, M. Lutman, V. Bosiljkov, Robustness of hollow clay masonry units and seismic behaviour of masonry walls, Construct. Build. Mater. 20 (10) (2006) 1028-1039.

[71] M. Tondelli, K. Beyer, M. DeJong, Influence of boundary conditions on the outof-plane response brick masonry walls in buildings with RC slabs, Earthq. Eng. Struct. Dynam. (2016).

[72] Y. Tu, T. Chuang, P. Liu, Y. Yang, Out-of-plane shaking table tests on unreinforced masonry panels in RC frames, Eng. Struct. 32 (2010) 3929-3935.

[73] J. Varela-Rivera, M. Polanco-May, L. Fernandez-Baqueiro, E. Moreno, Confined masonry walls subjected to combined axial loads and out-of-plane uniform pressures, Can. J. Civ. Eng. 39 (2012) 439-447.

[74] J.L. Varela-Rivera, D. Navarrete-Macias, L.E. Fernandez-Baqueiro, E.I. Moreno, Out-of-plane behaviour of confined masonry walls, Eng. Struct. 33 (5) (2011) 1734-1741.

[75] H. Varum, A. Furtado, H. Rodrigues, J. Dias-Oliveira, N. Vila-Pouca, A. Arêde Seismic performance of the infill masonry walls and ambient vibration tests after the Ghorka 2015, Nepal earthquake, Bull. Earthq. Eng. 15 (3) (2017) $1185-1212$.

[76] R. Vicente, H. Rodrigues, H. Varum, A. Costa, R. Mendes da Silva, Performance of masonry enclosure walls: lessons learned from recent earthquakes, Earthq. Eng. Eng. Vibrat. 11 (1) (2012) 23-34.

[77] S. Yatağan, Damages and failures observed in infill walls of reinforced concrete frame after 1999 Kocaeli earthquake, ITU J Faculty Arch. 8 (1) (2011) 219-228.

[78] R. Zarnic, S. Gostic, A. Crewe, A. Taylor, Shaking table tests of 1:4 reduced cale models of masonry infilled reinforced concrete frame buildings, Earthq. Eng. Struct. Dynam. 30 (2001) 819-834. 